\title{
Examination of the leaf proteome during flooding stress and the induction of programmed cell death in maize
}

\author{
Yu Chen, Xi Chen, Hongjuan Wang, Yiqun Bao and Wei Zhang*
}

\begin{abstract}
Background: Maize is a major economic crop worldwide, with substantial crop loss attributed to flooding. During a stress response, programmed cell death (PCD) can be an effective way for plants better adapt. To identify flooding stress related PCD proteins in maize leaves, proteomic analysis was performed using two-dimensional fluorescence difference gel electrophoresis (2D-DIGE) and mass spectrometry.

Results: Comparative proteomics was combined with physiological and biochemical analysis of maize leaves under flooding stress. Fv/Fm, qP, qN and relative water content (RWC) were found to be altered in response to flooding stress, with an increase in $\mathrm{H}_{2} \mathrm{O}_{2}$ content noted in vivo. Furthermore, DNA ladder detection indicated that PCD had occurred under flooding treatment. The maize leaf proteome was analyzed via 2D-DIGE gel, with a total of 32 differentially expressed spots isolated, 31 spots were successfully identified via MALDI-TOF/TOF MS which represent 28 proteins. The identified proteins were related to energy metabolism and photosynthesis, PCD, phytohormones and polyamines. To better characterize the role of translationally controlled tumor protein (TCTP) in PCD during a stress response, mRNA expression was examined in different plants by stress-induced PCD. These included heat stress induced rice protoplasts, Tobacco Mosaic Virus infected tobacco leaves and dark induced rice and Arabidopsis thaliana leaves, all of which showed active PCD, and TCTP expression was increased in different degrees. Moreover, S-adenosylmethionine synthase 2 (SAMS2) and S-adenosylmethionine decarboxylase (SAMDC) mRNA expression were also increased, but ACC synthase (ACS) and ACC oxidase (ACO) mRNA expression were not found in maize leaves following flooding. Lastly, ethylene and polyamine concentrations were increased in response to flooding treatment in maize leaves.
\end{abstract}

Conclusions: Following flooding stress, the photosynthetic systems were damaged, resulting in a disruption in energy metabolism, with the noted photosynthetic decline also possibly attributed to ROS production. The observed PCD could be regulated by TCTP with a possible role for $\mathrm{H}_{2} \mathrm{O}_{2}$ in TCTP induction under flooding stress. Additionally, increased SAMS2 expression was closely associated with an increased polyamine synthesis during flooding treatment.

Keywords: Maize, Programmed cell death, Flooding, Two-dimensional fluorescence difference gel electrophoresis, Translationally controlled tumor protein, S-adenosylmethionine synthase 2, Polyamine

\footnotetext{
*Correspondence: wzhang@njau.edu.cn

Department of Biochemistry and Molecular Biology, College of Life Science,

Nanjing Agricultural University, Nanjing, Jiangsu, PR, China
} 


\section{Background}

Programmed cell death genetically controls the rate of cell division and death to strictly regulate cell numbers in both animals and plants, thus ensuring that cells that are no longer needed can activate their own demise [1]. Studies have indicated that PCD cannot be limited to the regulation of development or reproduction, but is also implicated in plant senescence [2,3] and other process such as defense against biotic [4] and abiotic [5,6] stresses.

Flooding, a major abiotic stress, poses as a major constraint affecting crop growth, production and productivity in many agricultural regions worldwide [7]. The soil is considered to be flooded if there is freestanding water on the soil surface or if the available water fraction of the surface layer is at least $20 \%$ higher than the field capacity [8]. Maize is an important economic crop, with an estimated worldwide production of 839 million tons according to World Agricultural Supply and Demand Estimates report from October 11, 2012. However, in Southeast Asia, approximately $15 \%$ of the maize growing areas are affected by flooding, resulting in yearly production losses ranging from $25 \%$ - 30\%. In southeastern China, heavy rainfall leads to flooding that generally occurs during the maize seedling stage, resulting in severe seedling damage reducing maize production. While flooding is becoming a growing concern worldwide in numerous agriculture areas [9], recent evidence indicates that flood-induced PCD is related to aerenchyma formation and endogenous ethylene synthesis in maize [10].

To further characterize the molecular mechanisms regulating PCD in maize, proteomic analysis was employed. While proteomic approaches have been effective in characterizing protein expression patterns during stress responses [11], only a few proteomic studies have examined flooding or anoxia stresses in plants, which include tomato [11], rice [12], soybean [13], wheat [14] and maize [15]. Previous studies have indicated that an early rise in cytosolic $\mathrm{Ca}^{2+}$, an establishment of ionic homeostasis and root tip death may be essential adaptive changes enabling flood tolerance in maize [16]. To our knowledge, no proteomic study of maize leaf PCD during flooding has been examined. Our results indicated that following 4-days (4d) of flooding treatment, a conspicuous DNA ladder was noted in the third leaf, indicating the occurrence of PCD. Subsequently, third leaf total protein extracts were analyzed via two-dimensional fluorescence difference gel electrophoresis (2D-DIGE), and 28 proteins relating to energy metabolism/photosynthesis, PCD, phytohormones and polyamine-responsive proteins were identified. Furthermore, amongst various stresses including heat induced stress in rice protoplasts, Tobacco Mosaic Virus (TMV)-infected tobacco leaves and dark induced stress in rice and Arabidopsis thaliana leaves, all led to a relative increase in translationally controlled tumor protein (TCTP) mRNA expression and showed active PCD.

\section{Results and discussion}

Physiological measurements, in vivo $\mathrm{H}_{2} \mathrm{O}_{2}$ accumulation and induction of PCD in maize leaves during flooding

To study the role of maize physiology during flooding treatment, the maximum quantum yield of PSII (Fv/Fm), the photochemical quenching coefficient $(\mathrm{qP})$, the nonphotochemical quenching coefficient $(\mathrm{qN})$ and leaf relative water content (RWC) were analyzed in different leaves during various durations of treatment. After 2 days of flooding exposure, all of these factors showed little affected. However, after 3 days of treatment, Fv/Fm, $\mathrm{qP}$ and RWC were decreased in the first, second and third leaves, with a lesser change noted in the fourth leaves (Figure 1A,B,D). Moreover, the $\mathrm{qN}$ value was decreased in the first and second leaves after 3 days of flooding treatment and yet was increased in the third and fourth leaves, with no decrease noted in these leaves until reaching 4 days of treatment (Figure 1C). In Sorghum exposed to flooding stress, $\mathrm{Fv} / \mathrm{Fm}$ and $\mathrm{qP}$ significantly decreased, but $\mathrm{qN}$ increased substantially under saline conditions [17]. The noted $\mathrm{Fv} / \mathrm{Fm}$ ratio decrease indicates a down regulation of photosynthesis, or photoinhibition [18], and the relatively low leaf water content clearly predisposes the leaves to photoinhibitory damage [19]. The noted decreased in $\mathrm{qP}$ is considered indicative of a downregulation of electron transport [20] and the increase in qN reflects a reduced demand for electron transport products and an increased heat dissipation [21]. Furthermore, a maintenance or increase in $\mathrm{qN}$ values in stress situations has been associated with a protective response in order to avoid photoinhibitory damage to the reaction centres [22]. These findings suggested that after 4 days of flooding treatment, the photosynthetic systems of the first and second leaves were damaged and affected the third and fourth leaves. To investigate flood-induced $\mathrm{H}_{2} \mathrm{O}_{2}$ production, histochemistry utilizing 3, 3-diaminobenzidine (DAB) staining was employed. During DAB staining, the DAB reacts with $\mathrm{H}_{2} \mathrm{O}_{2}$ in a POX-dependent in situ histochemical reaction producing a red-brown polymerization product. This showed $\mathrm{H}_{2} \mathrm{O}_{2}$ accumulation following 3 days of flooding treatment, with more conspicuous accumulations noted after 4 days of treatment, with DAB coloration mainly observed on the surface of the first and second leaves and in the tips of the third leaves (Figure 1E). Previous studies have noted that when plants are subject to stress, such as plum pox viral (PPV) treatment, the redox balance can be easily disturbed and ROS accumulation in chloroplasts, probably by a disturbance of the electron transport chain [23]. In the present study, flooding induced changes in the $\mathrm{Fv} / \mathrm{Fm}, \mathrm{qP}, \mathrm{qN}$ and $\mathrm{H}_{2} \mathrm{O}_{2}$ levels, suggesting a decline in photosynthetic processes, possibly attributed 
A

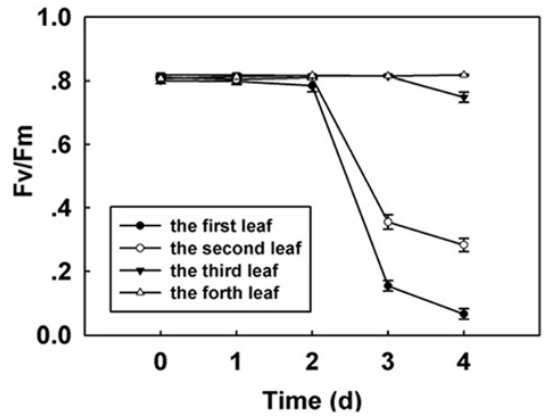

C

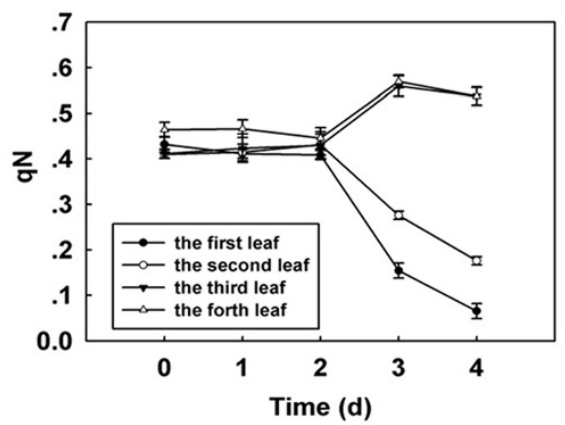

B

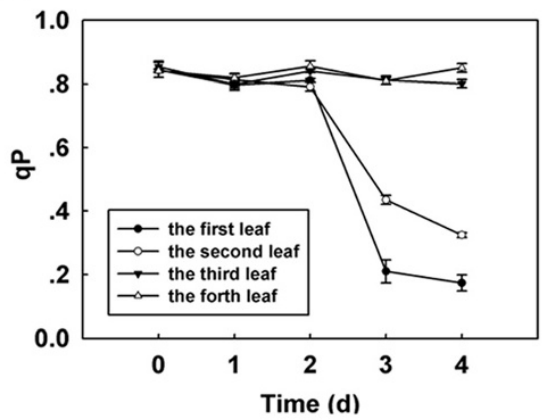

D

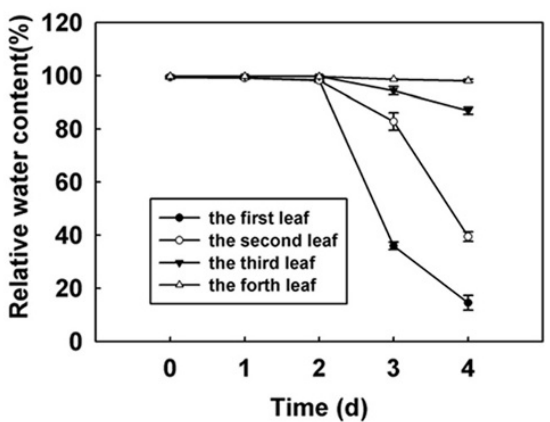

E
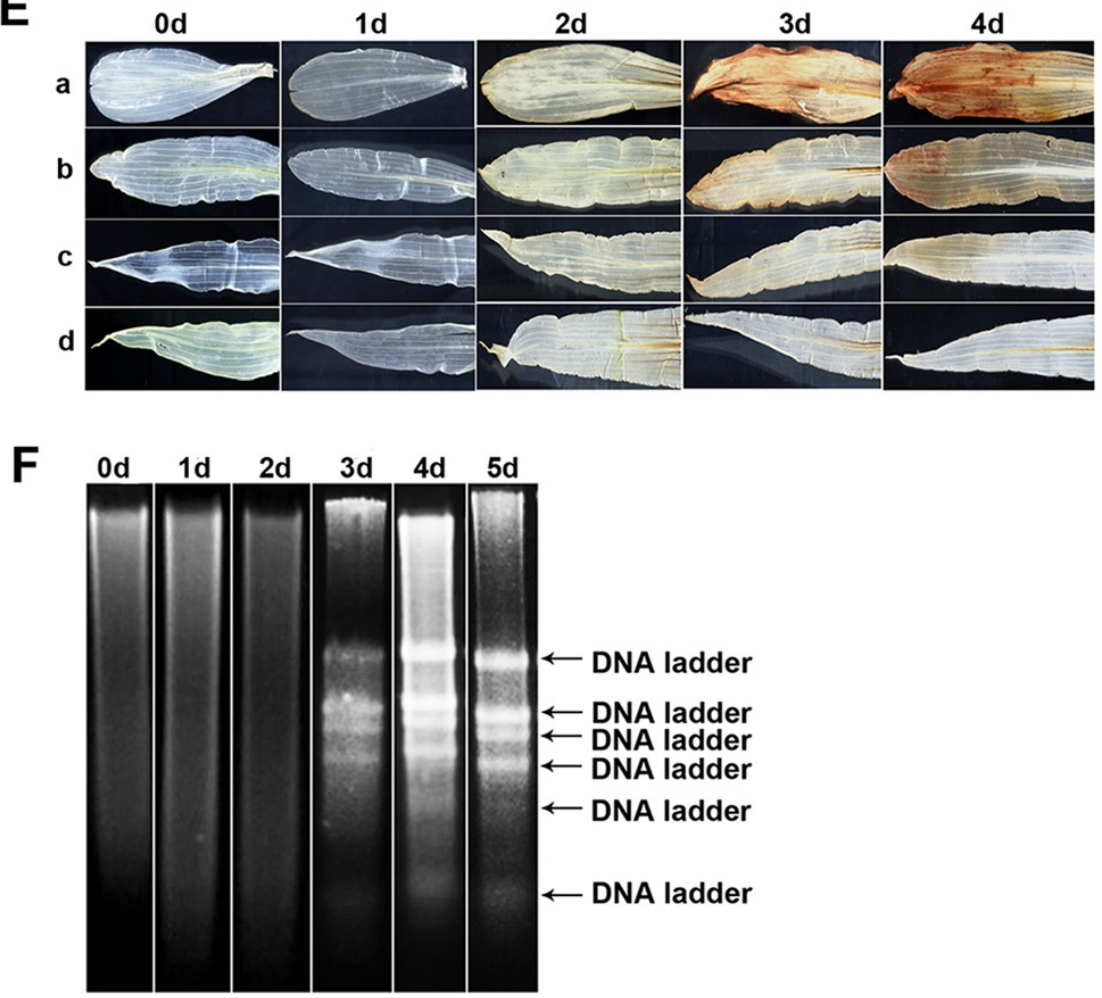

Figure 1 Physiological and biochemical analyzed maize leaves under flooding treatment. Comparisons of means of total $\mathrm{Fv} / \mathrm{Fm}$ ratio (A), qP (B), qN (C) and leaf relative water content (RWC) (D) under flooding treatment with all four leaves for 0, 1, 2, 3, 4 d. Vertical bars represent means $\pm S D(n=4)$ where these exceed the size of the symbol, as determined by Fisher's protected LSD test $(p<0.05)$. Time-course analysis of $\mathrm{H}_{2} \mathrm{O}_{2}$ production in maize leaves exposed to flooding treatment for $0,1,2,3,4$, to include the first leaf (a), second leaf (b), third leaf (c) and fourth leaf (d) (E). DNA laddering after different treatment times with flooding for 0, 1, 2, 3, 4, 5 d (F). 
to ROS production. As shown in Figure 1F, DNA laddering occurred following 3 days of flooding treatment, becoming more pronounced after 4 days of treatment and remained relatively the same after 5 days of treatment. The observed DNA laddering indicated the occurrence of $\mathrm{PCD}$, with the 3 day samples exemplifying the early stage of PCD, with the DNA laddering further elevated by day 4. Since this research was focused on the execution of PCD, the third leaf following 4 days of treatment was used for PCD characterization. Thus, flooding stress can contribute to a change in RWC, Fv/Fm, qP, and qN. Moreover, an accumulation of ROS can occur, to include $\mathrm{H}_{2} \mathrm{O}_{2}$ accumulation, leading to leaf senescence [24]. Additionally, the DNA ladder was assayed in the third leaves, suggesting that under flooding stress PCD may occur at the early stages [25].

\section{Proteomics: identification of differentially expressed proteins}

Equal amounts of protein from the control and treated leaved were labeled with Cy2 (internal standard), Cy3 or Cy5 dyes, with an overlay of the Cy3 and Cy5 images from the 2D-DIGE gels shown in Figure 2. In general, the protein expression patterns of treated samples were similar to those of the control leaves, with more than 2000 spots observed by the DIGE methodology. Following 2-DE image analysis, we found a number of spots with lower or higher protein abundances relative to the control leaves. A 2.5fold threshold limit was set in this study, with four replicates performed to reduce the number of potential false positives. Figure 2 shows a representative DIGE image of control and treated leaf protein extracts labeled with Cy3 and Cy5 and separated with IPG 4-7 strips and the spots
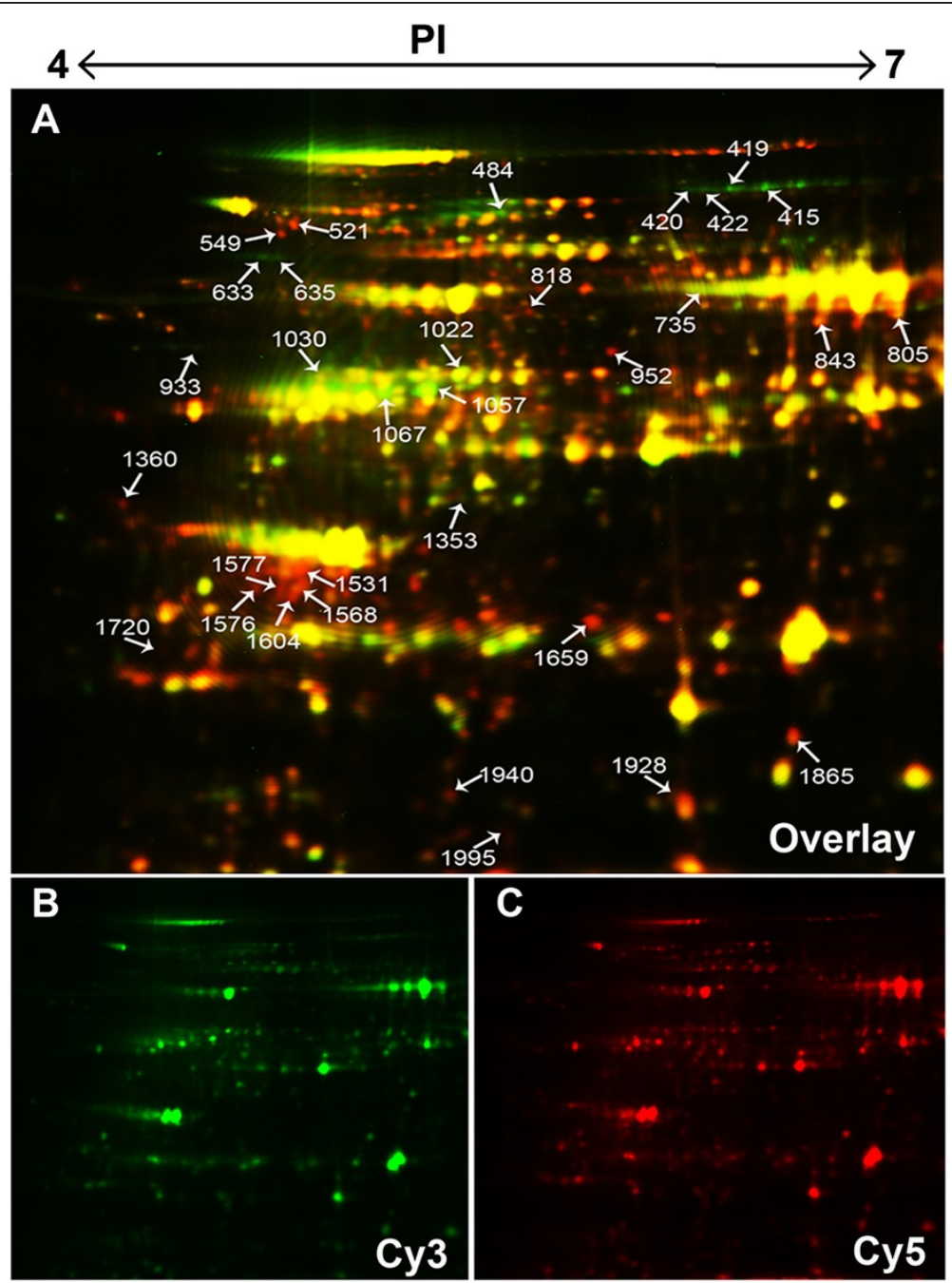

Figure 2 2D-DIGE images of total leaf proteins from the control and flooding treatments in maize. Extracts from control and treatment samples for four independent biological repeat experiments were differentially labeled with the Cy3 and Cy5 and separated by two-dimensional electrophoresis on 13- $\mathrm{cm}(\mathrm{pH} 4-7)$ IPG strips and 12.5\% polyacrylamide gels. Arrowed and numbered spots are differentially expressed protein spots in the image (A). Cy3-labeled control (B) and Cy5-labeled treatment (C) is shown. 
used for mass spectrometry analysis numbered, with some of these differential spots shown in the extended portion of the gels in Figure 3. Thirty-two spots showed at least a 2.5 -fold change in protein abundance $(\mathrm{p}<0.05)$ with 18 polypeptides exhibiting an increased expression and 14 polypeptides showing a decreased expression in the treated leaves relative to the control.

\section{Protein identification}

The 32 differentially expressed spots were further analyzed using MALDI-TOF/TOF MS analysis, with 31 spots were successfully identified by searching against the NCBInr and Viridiplantae EST databases (Table 1) which represent 28 proteins. According to NCBI gene annotations and the literatures, these proteins could be functionally classified into various groups, including energy metabolism and photosynthesis (41.9\%), PCD (32.3\%), phytohormones and polyamines (16.1\%) and others (9.7\%). Of the proteins relating to energy metabolism/photosynthesis, a protein related to IAA metabolism (spot 484) and a protein related to GA induced expression (spot 1995) from the $\alpha-A m y 1$ and $\alpha-A m y 2$ promoters [26] were identified. Moreover, proteins associated with ethylene metabolism (spots 1353 and 843) and the S-adenosylmethionine synthase 2 (spot 952) protein, which is involved in both ethylene and polyamine synthesis and relates to stress response, were also identified. Furthermore, 3-beta hydroxysteroid dehydrogenase/isomerase family protein (spot 1604), chitinase (spot 1360), harpin binding protein (spot 1568), pleckstrin homology domain containing, family A (spot 1928), developmentally regulated plasma membrane polypeptide 4 (DREPP4, spot 1576), fruit protein PKIWI502 (spot 1577), heat shock protein 70 (spot 521, 549) and putative heat shock protein translationally controlled tumor protein (TCTP, spot 1720) were all shown to be related to PCD. Therefore, these results indicate that flooding can affect energy metabolism/photosynthesis, phytohormones and polyamines, possibly leading to the induction of PCD.

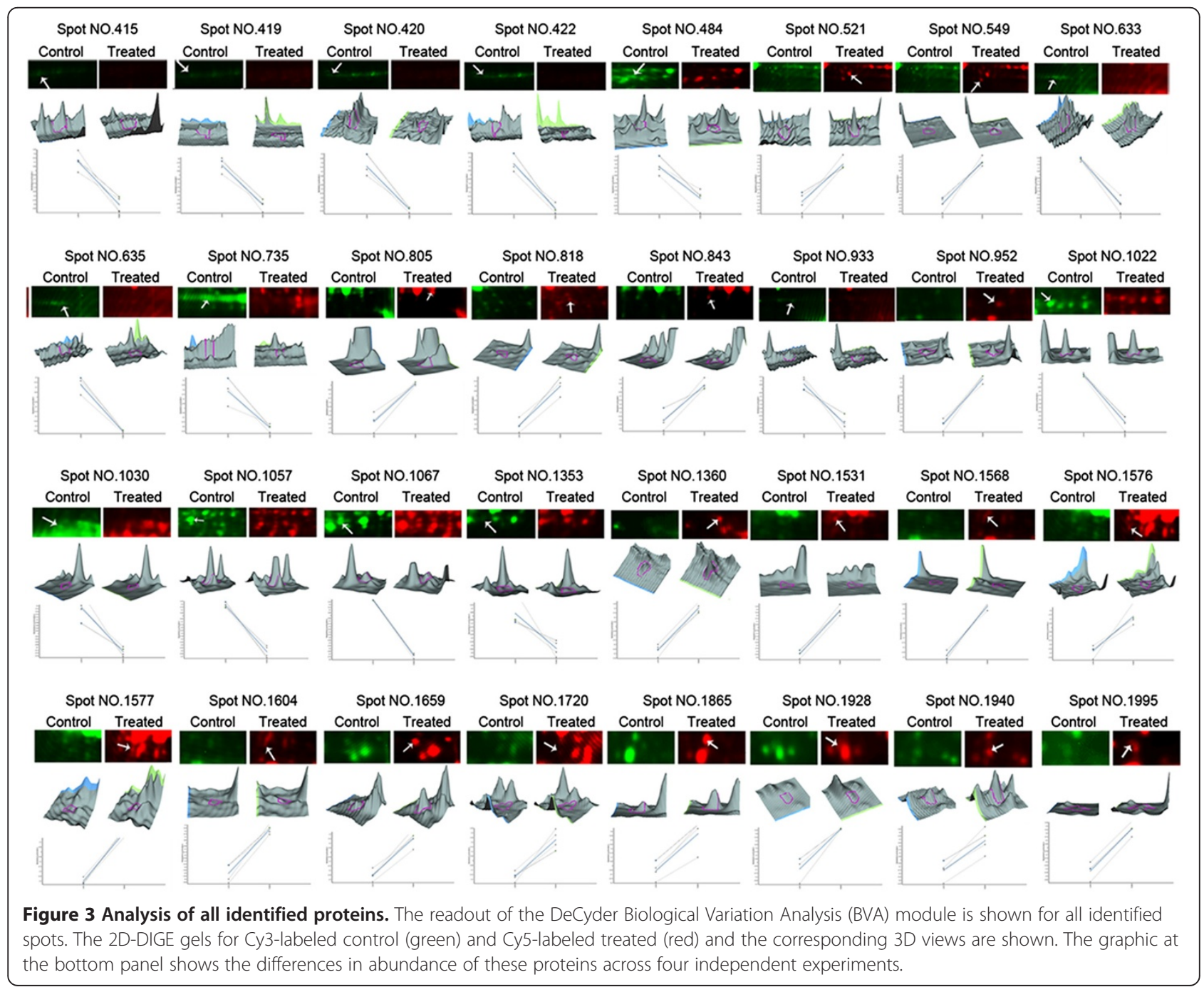


Table 1 Flooding treated responding proteins from maize leaves were analyzed by 2D-DIGE and MALDI-TOF/TOF

\begin{tabular}{|c|c|c|c|c|c|c|c|c|}
\hline Spots no. & Category and name & Gi number & TheroPI/Mr & Peptides matched & Coverage (\%) & Score & S.V.R. (Treated/Control) & $p$-Value \\
\hline \multicolumn{9}{|c|}{ Photosynthesis and energy metabolism related proteins } \\
\hline 415 & Phosphoenolpyruvate carboxykinase [ATP] [Zea mays] & gi|162457930 & $6.57 / 73781$ & 3 & 6 & 66 & -3.29 & 0.00034 \\
\hline 419 & Phosphoenolpyruvate carboxykinase [ATP] [Zea mays] & gi|162457930 & $6.57 / 73781$ & 3 & 6 & 92 & -3.06 & 0.00012 \\
\hline 420 & $\begin{array}{l}\text { Phosphoenolpyruvate carboxykinase, putative, expressed } \\
\text { [Oryza sativa Japonica Group] }\end{array}$ & gi|108707241 & $7.14 / 74523$ & 2 & 4 & 58 & -3.17 & 0.0029 \\
\hline 422 & Phosphoenolpyruvate carboxykinase [Zoysia japonica] & gi|58036453 & $6.49 / 72407$ & 2 & 1 & 56 & -3.34 & 0.0021 \\
\hline 633 & $\beta$-amylase & gi|1703302 & $4.88 / 55487.3$ & 8 & 8 & 155 & -4.58 & $2.30 \mathrm{E}-05$ \\
\hline 635 & $\begin{array}{l}\text { RuBisCO subunit binding-protein alpha subunit, chloroplast } \\
\text { precursor ( } 60 \mathrm{kDa} \text { chaperonin alpha subunit) }\end{array}$ & gi|115488160 & $5.12 / 61151$ & 2 & 5 & 87 & -3.09 & 0.00087 \\
\hline 735 & ATPase subunit 1 (mitochondrion) [Zea mays subsp. parviglumis] & gi|102567957 & $5.85 / 55430.9$ & 18 & 13 & 249 & -2.58 & 0.013 \\
\hline 933 & Fructose-1,6-bisphosphatase [Zea mays] & gi|226498474 & $5.07 / 44512.36$ & 4 & 12 & 185 & -3.2 & 0.00023 \\
\hline 1022 & Malate dehydrogenase 1 [Zea mays] & gi|195612678 & $6.49 / 47385$ & 4 & 10 & 253 & -3.69 & $1.10 \mathrm{E}-05$ \\
\hline 1030 & Phosphoglycerate kinase [Zea mays] & gi|223975935 & $5.21 / 43227$ & 9 & 18 & 344 & -2.52 & 0.00065 \\
\hline 1057 & $\begin{array}{l}\text { Ribulose bisphosphate carboxylase/oxygenase activase, } \\
\text { chloroplastic precursor [Zea mays] }\end{array}$ & gi|162458161 & $6.29 / 48079$ & 5 & 16 & 275 & -6.11 & $7.20 \mathrm{E}-06$ \\
\hline 1067 & Adenosine kinase [Zea mays] & gi|4582787 & $5.23 / 36465.5$ & 11 & 4 & 179 & -10.45 & $5.10 \mathrm{E}-06$ \\
\hline 1531 & Oxygen-evolving enhancer protein 1 [Zea mays] & gi|195619530 & $5.59 / 34783$ & 2 & 8 & 72 & 5.31 & $6.60 \mathrm{E}-06$ \\
\hline 1659 & $50 S$ ribosomal protein L21 [Zea mays] & gi|195609236 & $4.66 / 13133.9$ & 3 & 17 & 92 & 2.57 & 0.00037 \\
\hline \multicolumn{9}{|c|}{ PCD related proteins } \\
\hline 521 & Heat shock protein 70 [Arabidopsis thaliana] & gi|6746592 & $5.13 / 71056.4$ & 2 & 4 & 67 & 3.46 & 0.00056 \\
\hline 549 & Heat shock protein 70 [Arabidopsis thaliana] & gi|6746592 & $5.13 / 71056.4$ & 2 & 3 & 68 & 4.09 & 4.70E-05 \\
\hline 1360 & Chitinase [Zea mays subsp. parviglumis] & gi|214015047 & $4.88 / 34474.7$ & 6 & 8 & 171 & 2.89 & $3.00 \mathrm{E}-05$ \\
\hline 1568 & Harpin binding protein 1 [Oryza sativa Indica Group] & gi|38679325 & $8.92 / 28360.16$ & 2 & 5 & 73 & 3.18 & 0.00013 \\
\hline 1576 & DREPP4 protein [Zea mays] & gi|195638402 & $4.89 / 22595.9$ & 9 & 31 & 203 & 2.6 & 0.00078 \\
\hline 1577 & Fruit protein PKIWI502 [Zea mays] & gi|195624268 & $6.62 / 31174.73$ & 4 & 20 & 154 & 3.15 & 0.0001 \\
\hline 1604 & 3-beta hydroxysteroid dehydrogenase/isomerase family protein [Zea mays] & gi|195642948 & $7.63 / 32772.2$ & 4 & 20 & 150 & 5.17 & 0.00015 \\
\hline 1720 & Translationally-controlled tumor protein [Zea mays] & gi|195605582 & $4.52 / 18773.4$ & 5 & 6 & 88 & 2.52 & 0.00053 \\
\hline 1928 & Pleckstrin homology domain containing, family A [Zea mays] & gi|195641188 & $6.52 / 22785.4$ & 7 & 9 & 53 & 3.4 & 0.006 \\
\hline \multicolumn{9}{|c|}{ Phytohormone and polyamine related proteins } \\
\hline 484 & Aux/IAA protein [Solanum tuberosum] & gi|25989504 & $7.82 / 37018.4$ & 11 & 15 & 73 & -2.58 & 0.0032 \\
\hline 843 & Controlling leaf angle [Zea mays] & gi|343781534 & $4.74 / 43900.4$ & 10 & 10 & 55 & 2.71 & 0.0036 \\
\hline 952 & S-adenosylmethionine synthase 2 & gi|127046 & $5.57 / 43618$ & 1 & 3 & 87 & 3.39 & 0.0006 \\
\hline 1353 & PISTILLATA-like MADS box protein [Crocus sativus] & gi|78146198 & $9.26 / 24915.8$ & 11 & 9 & 64 & -3.2 & 0.0057 \\
\hline 1995 & HRT transcription factor [Zea mays] & gi|323388729 & $9.71 / 60370.4$ & 17 & 24 & 83 & 3.81 & 0.0046 \\
\hline
\end{tabular}


Table 1 Flooding treated responding proteins from maize leaves were analyzed by 2D-DIGE and MALDI-TOF/TOF (Continued)

Other proteins

$805 \quad$ Unknown [Zea mays]

$\mathbf{8 1 8}$ Hypothetical protein [Zea mays]

1940 OSJNBb0003B01.14 [Oryza sativa Japonica Group]

gi|194695026 6.52/42290.

gi|195612760 5.61/41336.1

gi|58531981 $\quad 6.02 / 192426.8$

\begin{tabular}{cccc}
14 & 434 & 2.66 & 0.00056 \\
7 & 128 & 2.61 & 0.0057 \\
12 & 79 & 2.79 & 0.0095 \\
\hline
\end{tabular}




\section{mRNA expressional analysis of differentially expressed proteins via qRT-PCR}

Gene expression at the transcription level was examined in 19 identified proteins via qRT-PCR (Figure 4). When maize was subjected to moderate flooding stress, several genes such as PEPCK, PGK, AUX/IAA, Plmbp, Hsp70, Chitinase and DREPP were up-regulated [27]. Our results indicated that the mRNA expression levels of PEPCK, Fbp, PGK, AUX/IAA, CLA, Plmbp and HRT increased following 1 day of treatment, but showed a dramatic decrease in the subsequent treatments. Furthermore, twelve transcripts (MDH1, ADK, OEE1, Hsp70, Chitinase, HrBP1, DREPP4, Fp PKIWI 502, 3- $\beta$ HSD, 50 S RPL21, TCTP and Phlda1) showed increased expression levels following 4 days of flooding treatment. It has been suggested that low oxygen levels can lead to gene expression reprogramming to help the plant withstand stress, as well as to maintain photosynthesis, metabolism and complement auxin at optimum levels [27], whereas the severe stress may damage the photosynthetic system, disrupting energy and auxin metabolism. However, the transcriptional expression levels of four genes ( $M D H 1, A D K, C L A$ and $H R T)$ were different from the observed protein expression levels, making it insufficient to predict protein expression levels from quantitative mRNA data. This phenomenon has been observed in many other studies and is mainly due to the transcriptional, post-transcriptional, translational and posttranslational events regulating expression [28-30].

\section{Photosynthesis and energy metabolism response of maize leaves during flooding stress}

Rubisco is a major photosynthetic protein and is involved in the respiratory pathway in plants. In the present study, the RuBisCO subunit binding-protein alpha subunit (spot 635) and RuBisCO activase (spot 1057) which correspond to Rubisco were down-regulated. Analogous our results, down-regulation of the Rubisco-binding protein (chaperonin 60) and Rubisco activase have been previously reported under flooding conditions [31]. These findings may be key to the decreased chlorophyll content and photosynthetic rate, with some reports indicating that Rubisco is gradually degraded during leaf senescence [32-34], possibly indicating that flooding stress may accelerate leaf senescence. Phosphoglycerate kinase (spot 1030), participates in the Calvin cycle and catalyzes an ATP-dependent reaction to form 1,3-bisphosphoglycerate from phosphorylate 3-phosphoglycerate [35]. Down-regulation of this enzyme could indicate a decrease in photosynthetic carbon assimilation during flooding conditions. An up-regulation in oxygen-evolving enhancer protein 1 (OEE1, spot 1531), which is bound to photosystem II (PSII) on the luminal side of the thylakoid membrane and is the most important protein for oxygen evolution and PSII stability [36], was also noted. Some evidence suggested that OEE1 is involved in recovery/turnover, which maintains the capacity of PSII during salinity and drought stress [36-38], yet little evidence supports that OEE1 is associated with flooding stress. We postulate that the up-regulation of OEE1 might repair protein damage and keep oxygen evolving under flooding conditions. Additionally, the $50 \mathrm{~S}$ ribosomal protein L21 protein (spot 1659) was also upregulated and has been implicated in the transformation of proplastids to chloroplasts [39]. We postulate that as chloroplast damage occurs under flooding conditions and that the $50 \mathrm{~S}$ ribosomal protein L21 protein could accelerate the transformation of proplastids to chloroplasts for survival. While ATP is an important energy source, ATP synthesis is low in the mitochondria during the oxygen deprivation that is experienced during flooding condition [40]. Adenosine kinase (ADK, spot 1067) is a housekeeping enzyme that catalyzes the phosphorylation of adenosine (Ado) into adenosine monophosphates (AMP) [41]. ADK and ATPase subunit 1 (spot 735) were found to be down-regulated, possibly due to an $\mathrm{O}_{2}$ and ATP reduced availability [42]. Other downregulated proteins included $\beta$-amylase (spot 633), which is involved in the degradation of starch to sucrose [43], malate dehydrogenase 1 (spot 1022), phosphoenolpyruvate carboxykinase (spot 415, 419, 420, 422) and fructose-1, 6-bisphosphatase (spot 933) which all play a key role in gluconeogenesis. Collectively, these findings indicated that a lack of sugar production in hypoxic plants could restrict essential metabolites and in turn reduce energy consumption [42]. Additionally, sugar fermentation plays a key role in root tip acclimation during anoxia [15], with the current study noting an inhibition of enzymes pertaining to gluconeogenesis, thus enhancing fermentation.

\section{PCD response to flooding stress}

Plants subjected to biotic or abiotic stresses can experience PCD, while flooding conditions damaged crops due to anoxia, leading to an increased risk of plant disease and insect infestations [44]. Three proteins corresponding to diseases resistance, including 3-beta hydroxysteroid dehydrogenase/ isomerase family protein (spot 1604), chitinase (spot 1360) and harpin binding protein 1 (HrBP1, spot 1568), were found to be up-regulated during flooding stress. A previous study found that following $R$. solani infection, the 3-beta hydroxysteroid dehydrogenase/isomerase family protein was induced in resistant rice, suggesting that this enzyme may play a role in the synthesis and regulation of steroids associated with disease resistance [45]. HrBP1 can induce plants to generate systemic acquired resistance and plays an important biological role in pest control [46], with its up-regulation able to induce resistance against viruses, fungi, bacteria and pests in plants [47]. Chitinase, a pathogenesis related (PR) protein, has been reported to strengthen the plant immune response against a variety of 


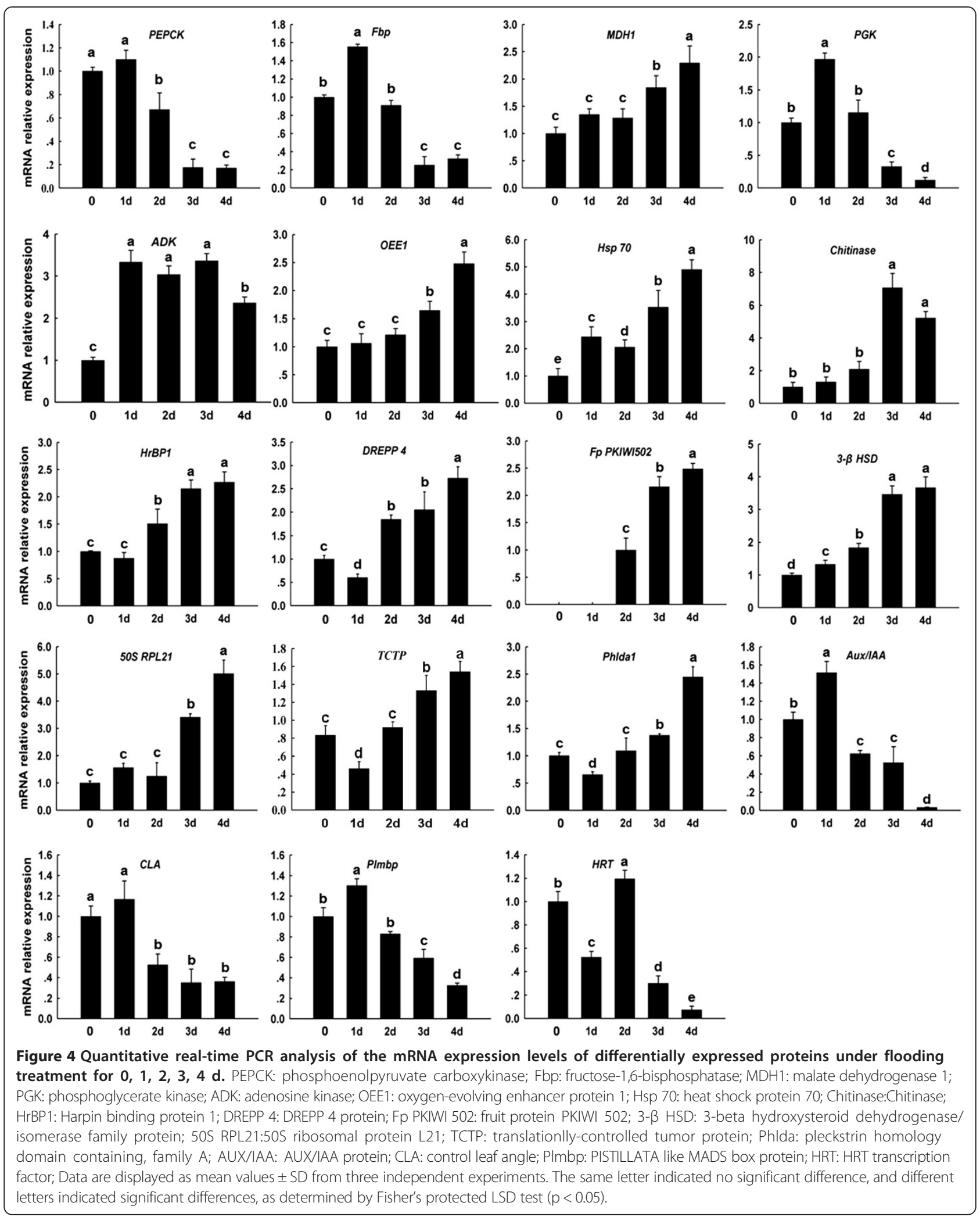


pathogens and has been noted to increase in response to numerous abiotic agents [48]. Additionally, previous studies have described the induction of PR proteins in response to both biotic and abiotic stresses, such as viral infection or salt stress treatment, and shown that PR induction can prevent opportunistic fungal or bacterial infections when the plant is in a weaken state [49-51]. Fruit protein PKIWI502 (spot 1577), who's functions relate to FAD-dependent oxidoreductase, was also upregulated. Oxidoreductase has been reported to show increased levels under flooding conditions [52], in addition to AIF, a FAD-dependent oxidoreductase, that regulates PCD [53]. Thus, we propose that fruit protein PKIWI502 could also regulate PCD. Pleckstrin homology domain containing, family A (Phlda1, spot 1928) was found to be up-regulated and has been associated with apoptosis in $\mathrm{T}$ cell hybridomas, neuronal and melanoma cells [54-56], but little has been reported in plants. DREPP4 (spot 1576) has been found to be a developmentally regulated plasma membrane polypeptide in tobacco [57]. DREPP-like protein, a calmodulin [58], was found to temporarily increase after cold acclimation [59], while DREPP 4 has been associated with defense response [60]. Additionally, an early rise in cytosolic $\mathrm{Ca}^{2+}$, as well as an establishment of ionic homeostasis was found to be essential for the induction of adaptive changes in response to flooding treatment in maize [16]. Moreover, changes in protein synthesis are required during hypoxia for improved cytoplasmic $\mathrm{pH}$ regulation and survival [15]. Together, these findings suggest that DREPP4 may play a key role in ionic homeostasis and be associated with $\mathrm{Ca}^{2+}$-mediated PCD. The up-regulation of heat shock protein 70 (hsp70, spot 521, 549) during flooding has been previously reported $[15,61]$ and has been found to suppress PCD in rice protoplasts [62]. An increased expression of TCTP (spot 1720) has been reported under a variety of stress conditions in humans and Mytilus galloprovincialis, with TCTP functioning in the maintenance of heat stability and induction of cell death $[63,64]$. While little has been reported relating TCTP to PCD during maize stress response, our findings showed an up-regulation of TCTP during flooding in maize. Additionally, we analyzed TCTP transcriptional levels during stress induced PCD in various plants. Arabidopsis plants were incubated in the dark for 24, 36, 48, 60 and $72 \mathrm{~h}$ and showed an unaltered morphology (Figure 5A), while TCTP mRNA expression levels increased proportionately to the dark exposure duration (Figure 5B). Additionally, dark-induced rice experienced greater degrees of etiolation following exposure, with TCTP mRNA expression levels peaking at $36 \mathrm{~h}$ and then decreasing (Figures $5 \mathrm{C}$ and D). Rice exposed to heat stress showed DNA laddering, indicating the occurrence of PCD in rice protoplasts, with DNA laddering occurring at $2 \mathrm{~h}$, becoming significant by $4 \mathrm{~h}$ and decreasing at $6 \mathrm{~h}$ (Figure 5E). TCTP mRNA expression levels were increased at $6 \mathrm{~h}$ relative to the control (Figure 5F). Hsr203j, the hypersensitivity (HR) molecular marker gene that accumulates specifically in tissues, was examined following TMV infection. This showed the hsr203J mRNA expression at $5 \mathrm{~h}$ to be approximately 2.6-fold higher than the control (Figure 5G), demonstrating that hypersensitivity (HR)-like cell death was induced by TMV. Furthermore, TCTP mRNA expression at $7 \mathrm{~h}$ was approximately 2.3 -fold higher than the control. (Figure 5H). In Arabidopsis, PCD was shown to inhibit TCTP, with TCTP able to significantly diminish tunicamycin induced cell death and able to affect expression of the anti-apoptotic protein BAX [65]. These findings further suggest that TCTP plays a role in PCD during a stress response and TCTP may be a regulator of PCD in maize. In the present study, we observed an accumulation of $\mathrm{H}_{2} \mathrm{O}_{2}$ in leaves as a result of flooding stress (Figure 1E). In a previous study, $\mathrm{H}_{2} \mathrm{O}_{2}$ inhibition was found to induce TCTP protein expression in pea seeding [66], thus collectively suggest a possible role of $\mathrm{H}_{2} \mathrm{O}_{2}$ in TCTP induction during flooding stress.

\section{Phytohormone and polyamines response to flooding stress}

When under hypoxia tolerance, plant species elongate their petioles to reach the surface of the water and promote survival, with ethylene, auxin, abscisic acid, gibberellic acid and polyamines directing this signal transduction cascade $[67,68]$. Ethylene (ET) is a simple gaseous plant hormone involved in numerous biological process like leaf abscission, senescence, growth regulation, fruit ripening and many stress acclimations [69]. Polyamines are involved in a wide array of fundamental plant processes such as growth, development, senescence, membrane stabilization and adaptation to abiotic and biotic stresses [68]. In our study, we found the ethylene and polyamine levels to increased 4 days post-flooding treatment (Figure 6). S-adenosylmethionine synthase 2 (SAMS2, spot 952) is a key enzyme in the synthesis of S-adenosylL-methionine (SAM), a precursor for the biosynthesis of ethylene and polyamines [70], and was found to be upregulated. SAM is converted into ethylene by ACC synthase (ACS) and ACC oxidase (ACO) [71]. Spermidine and spermine synthesis required decarboxylated $\mathrm{S}$ adenosylmethionine (dcSAM), which is produced from SAM by the action of S-adenosylmethionine decarboxylase (SAMDC) [72]. However, in our study, the expression of SAMS2 and SAMDC increased after 4 days of treatment, with the expression of ACC synthase and ACC oxidase not established (Figure 6). Previous studies have found that under anaerobic conditions, ACC production is localized in the roots [73] and that ACO1 expression was lowest in the shoot [74]. Thus in the current study, SAMS2 was closely related to polyamines synthesis, while 
C

A

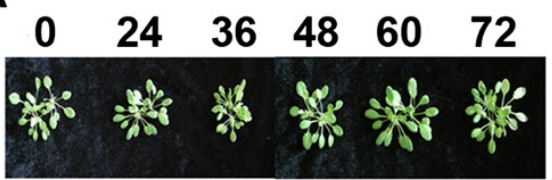

B

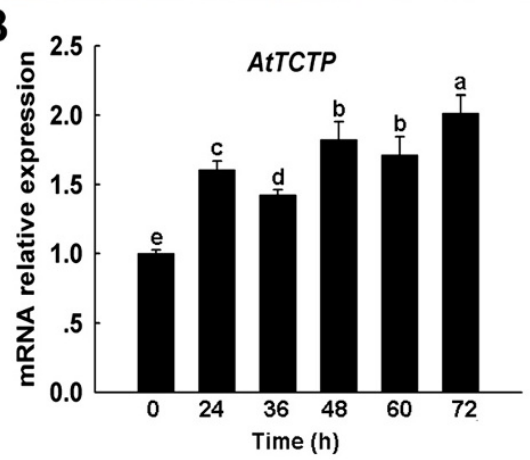

$\mathbf{E}$

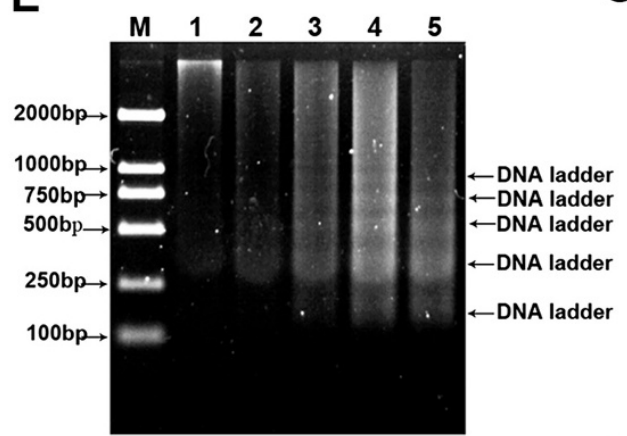

$\mathbf{F}$

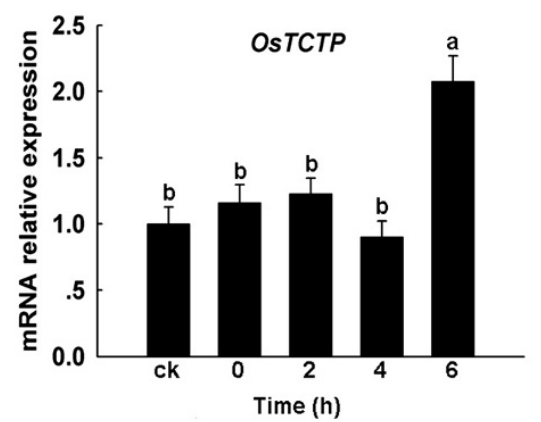

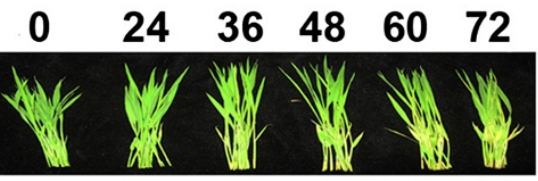

D

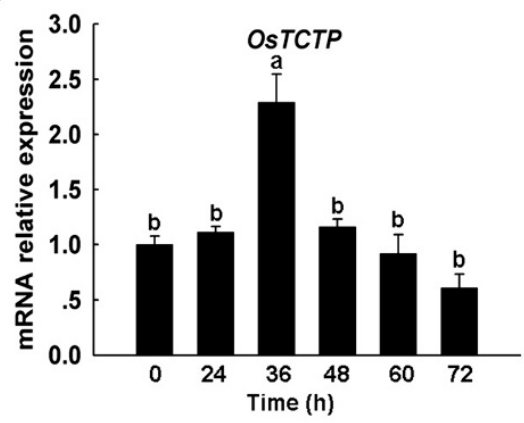

G

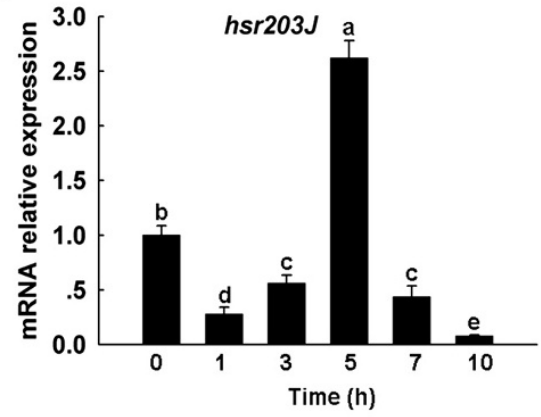

H

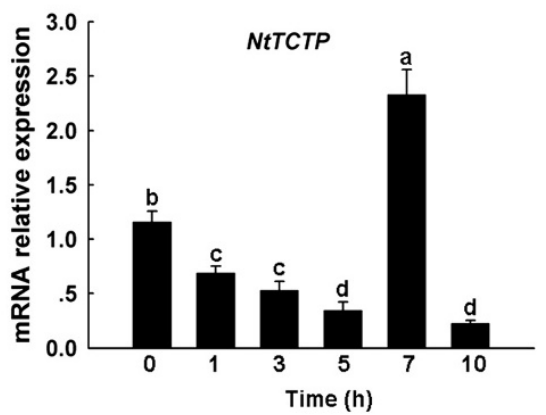

Figure 5 Quantitative Real-time RT-PCR analysis of the mRNA expression levels of TCTP in various plants by PCD induction. The morphology of Arabidopsis was induced by dark for $0,24,36,48,60,72 \mathrm{~h}$ (A). qRT-PCR analysis of TCTP mRNA expression levels in dark-induced Arabidopsis for $0,24,36,48,60,72 \mathrm{~h}$ (B). The morphology of rice was induced by dark for 0, 24, 36, 48, 60, $72 \mathrm{~h}$ (C). qRT-PCR analysis of TCTP mRNA expression levels in dark-induced rice for $0,24,36,48,60,72 \mathrm{~h}$ (D). DNA laddering in rice protoplasts after heat treatment was detected by agarose electrophoresis. Protoplasts were treated at $48^{\circ} \mathrm{C}$ for $15 \mathrm{~min}$ and allowed to recover at $28^{\circ} \mathrm{C}$ for $0,2,4,6 \mathrm{~h}$. Lane M: Marker; Lane 1: untreated (ck); Lane 2: recovered for 0 h; Lane 3: recovered for 2 h; Lane 4: recovered for 4 h; Lane 5: recovered for 6 h (E); qRT-PCR analysis of TCTP mRNA expression levels in heat shock rice protoplasts for ck, 0, 2, 4, $6 \mathrm{~h}$ (F). qRT-PCR analysis for quantitative analysis of hsr203J (G) and TCTP (H) mRNA expression levels after TMV-infected tobacco for $0,1,3,5,7,10 \mathrm{~h}$. Data are displayed as mean values \pm SD from three independent experiments. The same letter indicated no significant difference, and different letters indicated significant differences, as determined by Fisher's protected LSD test $(p<0.05)$

ethylene production was inhibited. Our study found the ethylene concentrations to increase, possibly due to ACC being transported from roots to leaves and converted into ethylene [73], while other papers have suggested that the xanthine oxidase-xanthine reaction reduces oxygen to both $\mathrm{O}_{2}^{-}$and $\mathrm{H}_{2} \mathrm{O}_{2}$, which in the presence of transition metals generate hydroxyl radicals that act upon methional to release ethylene [75]. The leaf angle control protein was 

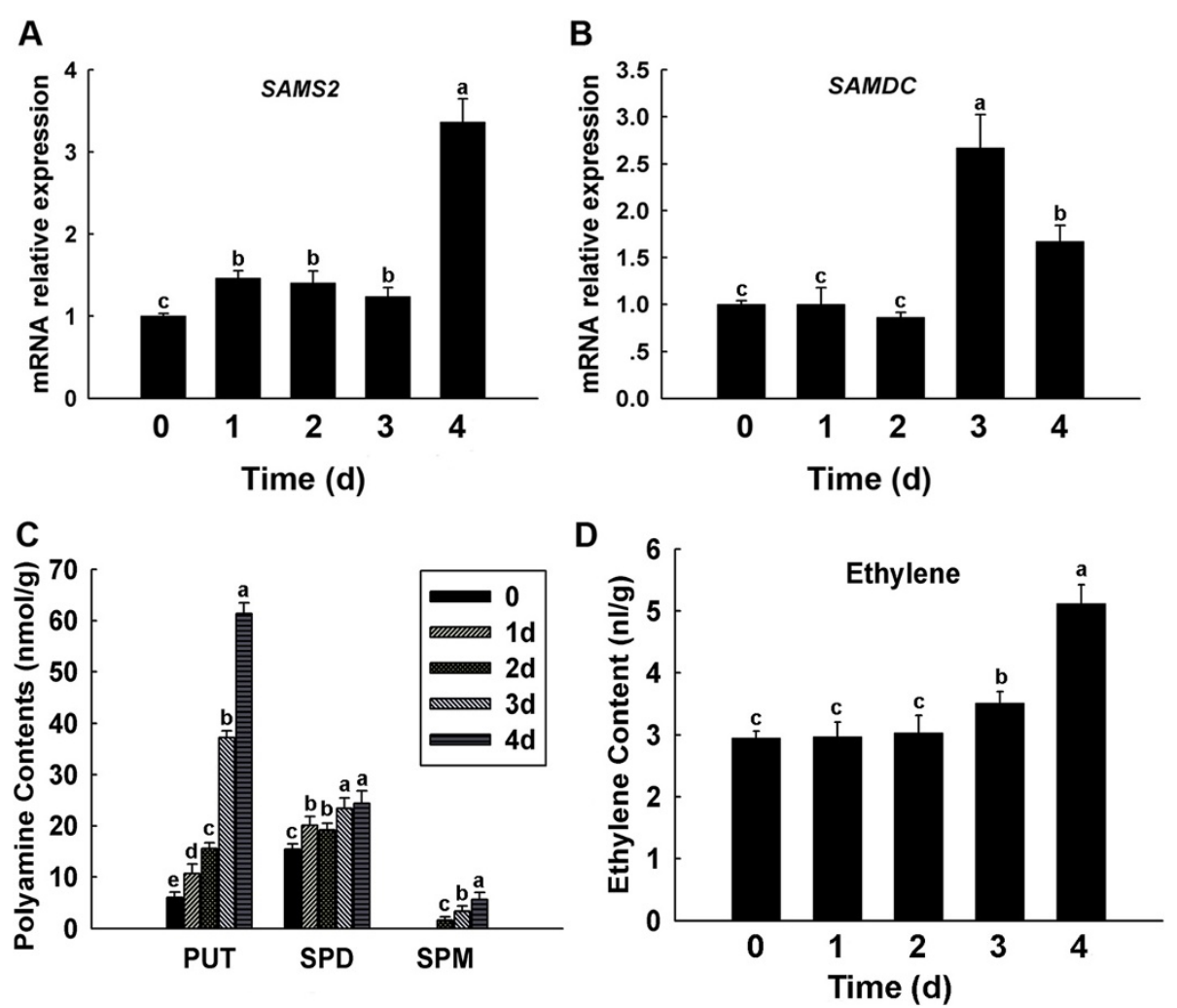

Figure 6 Quantitative Real-time RT-PCR analysis of the mRNA expression levels of SAMS2, DAMDC and polyamines, ethylene contents in maize leaves under flooding treatment for $\mathbf{0}, \mathbf{1}, \mathbf{2}, \mathbf{3}, \mathbf{4}$ d. qRT-PCR assays for quantitative analysis of SAMS2 (A) and SAMDC (B) mRNA expression levels under flooding treatment. HPLC assays of polyamine content in maize leaves under flooding treatment; putrescine (PUT), spermidine (SPD) and spermine (SPM) (C). Gas chromatograph (GS) assays of ethylene content in maize leaves under flooding treatment; Ethylene contents (D). Data are displayed as mean values \pm SD from three independent experiments. The same letter indicated no significant difference, and different letters indicated significant differences, as determined by Fisher's protected LSD test $(p<0.05)$.

shown to be up-regulated, possibly because during flood condition plants angle the leaves upward to keep a portion of the leaves above water, with ethylene possibly promoting this response [76]. Additionally, ethylene regulates PISTILLATA-like MADS box protein expression, which is involved in ovary development and whose expression decreases following pollination [77]. In our study, ethylene expression increases in response to flooding stress and we hypothesis that ethylene play a role in inhibiting PISTILLATA-like MADS box protein expression during flooding. The gibberellin response element (GARE) of $\alpha$-amylase promoters plays a central role in GA-regulated gene expression. HRT is a zinc-finger protein that binds the 21 nucleotide GARE and can repress GA-induced expression from the $\alpha-A m y 1$ and $\alpha$-Amy 2 promoters [26]. In our results, the expression of HRT was increased, while $\beta$-amylase and $\mathrm{GA}_{3}$ were decreased in the leaves during flooding treatment (Figure 7). Thus, flooding could inhibit GA synthesis in the roots, thus leading to a decrease in leaves, while the decrease in $\beta$-amylase expression may relate to feedback leading to accumulation of
HRT. GA and ABA are antagonists and ABA could prevent the expression of amylase [78], with previous studies noting an increase in ABA expression during flooding conditions [79]. These findings were consistent with our results that noted an increase in ABA expression after 4 days of flooding treatment (Figure 7). Previous studies have found plants under flooding stress exhibit a decrease in GA expression and an increase in ABA expression, with reduced IAA concentrations noted in the leaves [80]. The present study, we also noted a decrease in IAA expression from the start of flooding (Figure 7). AUX/IAA protein is an active repressor, with its stability and activity modulated by auxin. As auxin concentrations eventually declined, AUX/IAA protein concentrations continue to climb until sufficient levels are reached to generate feedback [81]. However, in our study, the IAA concentration was lowest after 4 days of flooding treatment, with a decreased AUX/IAA protein expression also noted. It may be that as auxin concentrations eventually decline, that a delay occurs before AUX/ IAA protein levels are seen to increase and then be impacted by feedback. 

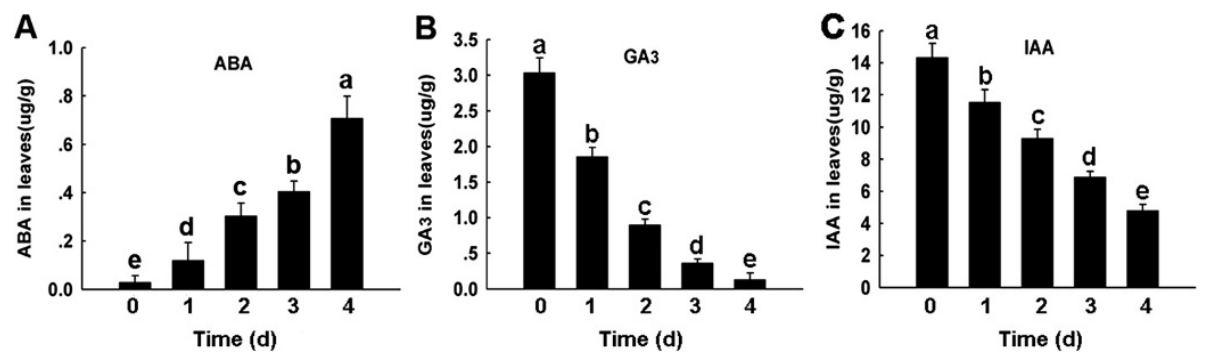

Figure 7 Phytohormones contents in maize leaves under flooding treatment for $\mathbf{0}, \mathbf{1}, \mathbf{2}, \mathbf{3}, \mathbf{4} \mathbf{d}$. UPLC assays of $A B A$, GA 3 and IAA contents in maize leaves under flooding treatment. Data are displayed as mean values \pm SD from three independent experiments. The same letter indicated no significant difference, and different letters indicated significant differences, as determined by Fisher's protected LSD test $(p<0.05)$.

\section{Conclusion}

In this study, we found PCD in the leaves of maize under flooding treatment and DIGE approaches to obtain a comprehensive proteomic description of flooding induced PCD was applied. A total of 32 differentially expressed spots were identified via 2D-DIGE, with 31 spots successfully identified by MALDI-TOF/TOF MS which represents 28 proteins. The identified proteins related to energy metabolism and photosynthesis, PCD, phytohormones and polyamines. All PCD related proteins exhibited an increased expression following flooding stress and TCTP was implicated as a potential PCD regulator in plants. Collectively, these findings shed light on flooding tolerance and show ability for Maize to restrict essential metabolites, thus reducing energy consumption, as a means to adapt to hypoxia. While the photosynthetic systems were damaged, the up-regulation of OEE1 appears to be able to maintain the PSII capacity during flooding stress. Furthermore, we observed an accumulation of $\mathrm{H}_{2} \mathrm{O}_{2}$ in leaves in response to flooding stress, thus suggesting a possible role of $\mathrm{H}_{2} \mathrm{O}_{2}$ in the induction of TCTP, whereas the photosynthetic decline may result in the ROS overproduction. Additionally, flooding induced a small amount of ethylene production, with a noted increase in SAMS2 expression relating to the accumulation of polyamines. This suggests that the accumulation of polyamines inhibited ethylene production to further delay senescence in maize leaves during flooding. Furthermore, the increased ethylene concentration may be due to ACC being transported from roots to leaves and converted into ethylene. In conclusion, this study lays the foundation for further investigations to enable the enhancement of flood tolerance in maize.

\section{Methods plant growth and flooding treatment}

Maize seeds (Zea mays L.cv Nongda 108; from Nanjing Agricultural University, China) were sown on plastic plates and grown in a light chamber at $22^{\circ} \mathrm{C}$ to $28^{\circ} \mathrm{C}$ with a photosynthetic active radiation of $300 \mu \mathrm{mol} \mathrm{m}^{-2} \mathrm{~s}^{-1}$ and a photoperiod of $14 / 10 \mathrm{~h}$ (day/night) and watered daily.
When the fourth leaves were fully expanded, they were subjected to flooding stress. To impose the treatment, seedling pots were in plastic containers $(55 \mathrm{~cm} \times 35 \mathrm{~cm} \times$ $10 \mathrm{~cm}$ ) and filled with water so that the water level was about $2 \mathrm{~cm}$ above the soil surface in the plant-containing pots [82], while control plants were appropriately watered during the experimental period. After 5 days of treatment, the $1^{\text {st }}, 2^{\text {nd }}, 3^{\text {rd }}$ and $4^{\text {th }}$ leaves from the bottom were sampled from both the treated and control plants.

\section{Physiological measurements}

Each experimental treatment was performed in quadruplicate. Chlorophyll fluorescence parameters were initially taken on dark-adapted leaves for $30 \mathrm{~min}$, using a chlorophyll fluorometer (FMS 1, Hansatech, Norfolk, UK) with an excitation soure intensity of $600 \mu \mathrm{mol} \mathrm{m}{ }^{-2} \mathrm{~s}^{-1}$. The maximum quantum yield of PSII (Fv/Fm), the photochemical quenching coefficient $(\mathrm{qP})$ and the non- photochemical quenching coefficient (qN) were calculated as described previously [83]. Individual leaves were removed from the steam and immediately weighed to determine the fresh mass (FM). To obtain the turgid mass (TM), leaves were floated in distilled water inside a closed petri dish. During the imbibitions period, after gently wiping the water from the leaf surface, leaf samples were weighed periodically, till constant. At the end of the imbibition period, leaf samples were placed at $80^{\circ} \mathrm{C}$ for $48 \mathrm{~h}$ to obtain the dry mass (DM). All mass measurements were made using an analytical scale (precision of $0.0001 \mathrm{~g}$ ) and relative water content calculated by the equation: RWC $(\%)=$ [(FM - DM)/(TM - DM)] [84].

\section{Histochemical detection of $\mathrm{H}_{2} \mathrm{O}_{2}$}

$\mathrm{H}_{2} \mathrm{O}_{2}$ was detected in the leaves of plants by using DAB as a substrate [85]. Plants were subjected flooding $4 \mathrm{~d}$, with the base of stem excised and a $1 \mathrm{mg} \mathrm{mL}^{-1}$ solution of DAB (pH 3.8) supplied for $8 \mathrm{~h}$ under light at $25^{\circ} \mathrm{C}$. Following treatment, the leaves were decolorized by immersion in boiling ethanol (96\%) for $10 \mathrm{~min}$. This treatment decolorized the leaves while leaving the deep brown polymerization 
product produced by the reaction of DAB with $\mathrm{H}_{2} \mathrm{O}_{2}$. After cooling, the leaves were photographed.

\section{DNA laddering analysis}

Half gram of flood treated or control leaves were ground into powder with liquid nitrogen, transferred into extraction buffer (100 mM Tris-HCl, pH 8.0, 20 mM EDTA, $1.4 \mathrm{M} \mathrm{NaCl}, 2 \%$ CTAB and $0.2 \% \beta$-mercaptoethanol) and incubated at $65^{\circ} \mathrm{C}$ for $1 \mathrm{~h}$. Then DNA was extracted with phenol/chloroform/isopropanol (25:24:1 by volume) and precipitated with isopropanol for $30 \mathrm{~min}$. Pellets were washed with $70 \%$ ethanol, dissolved in TE buffer (10 mM Tris- $\mathrm{HCl}, 1 \mathrm{mM}$ EDTA at $\mathrm{pH}$ 7.4) and treated with DNase-free RNase A to digest any remaining RNA. Finally, $10 \mu \mathrm{g}$ of DNA from each sample was separated by electrophoresis on a $2 \%$ agarose gel [86].

\section{Preparation of total protein extract}

Protein was extracted using Mg/NP-40 extraction buffer [87]. The leaves were placed in liquid nitrogen, transferred to a pre-chilled mortar and ground with a pestle in liquid nitrogen to a fine powder. The powder was homogenized in $10 \mathrm{ml}$ of ice-cold $\mathrm{Mg} / \mathrm{NP}-40$ extraction buffer containing $0.5 \mathrm{M}$ Tris- $\mathrm{HCl}, 2 \% \mathrm{v} / \mathrm{v}$ NP- $40,20 \mathrm{mM} \mathrm{MgCl}_{2}, 2 \% \mathrm{v} / \mathrm{v}$ $\beta$-mercaptoethanol, $1 \mathrm{mM}$ phenylmethylsulfonyl fluoride (PMSF) and $1 \% \mathrm{w} / \mathrm{v}$ polyvinylpolypyrrolidone (PVPP) at $\mathrm{pH}$ 8.3. After centrifugation at $13000 \times \mathrm{g}$ for $20 \mathrm{~min}$ at $4^{\circ} \mathrm{C}$, proteins were precipitated from the supernatant by adding six volumes of cold acetone at $-20^{\circ} \mathrm{C}$ overnight. After centrifugation at $13000 \times \mathrm{g}$ for $20 \mathrm{~min}$ at $4^{\circ} \mathrm{C}$, pellets were washed with ice-cold acetone containing $0.1 \% \mathrm{w} / \mathrm{v}$ DTT and centrifuged again, with the washing procedure repeated three times. Pellets were finally freeze-dried resuspended in labeling buffer ( $30 \mathrm{mM}$ Tris, $7 \mathrm{M}$ urea, $2 \mathrm{M}$ thiourea and $4 \% \mathrm{w} / \mathrm{v}$ CHAPS at $\mathrm{pH}$ 8.5). Protein content was determined via Bradford method with a bovine serum albumin standard to ensure a protein concentration between $5-10 \mathrm{mg} / \mathrm{ml}$.

\section{CyDyes fluorescence protein labeling and 2D-DIGE}

Leaf extracts were prepared and resolved by 2D-DIGE. Four gel analyses were performed according to the principles of experimental design in DIGE [88]. Each gel contained one control sample labeled with $\mathrm{Cy} 3$ fluorescent dye, one treated sample labeled with Cy5 fluorescent dyes and an internal standard containing equal amounts of all samples and Cy2 labeled. The CyDye DIGE Fluor minimal dye of DMF was reconstituted to make a stock of $1 \mathrm{nmol} / \mu \mathrm{l}$ and a subsequent working solution of $200 \mathrm{nmol} / \mu \mathrm{l}$. Mixed protein samples and fluorescent dyes $(50 \mu \mathrm{g}$ : $400 \mathrm{pmol})$ were incubated for $30 \mathrm{~min}$ on ice in the dark. The labeling reaction was ended by the addition of $10 \mathrm{mM}$ lysine for $10 \mathrm{~min}$. The three labeled samples were mixed to contain $50 \mu \mathrm{g}$ of $\mathrm{Cy} 3 / \mathrm{Cy} 5$ - labeled samples and $50 \mu \mathrm{g}$ of Cy2-labeled internal standard and adjusted with rehydration buffer $(8 \mathrm{M}$ urea, $4 \% \mathrm{w} / \mathrm{v}$ CHAPS, $2 \%$ DTT and $2 \% \mathrm{v} / \mathrm{v} \mathrm{pH} \mathrm{3-10}$ pharmalyte) to a final volume of $250 \mu \mathrm{l}$. The samples were separated in the first dimension by isoelectric focusing (IEF) at $20^{\circ} \mathrm{C}$ using an IPGphor3 isoelectric focusing system (GE Healthcare). The $13 \mathrm{~cm}$ 4-7 IPG strips (GE Healthcare) were incubated overnight with protein samples in rehydration buffer at room temperature. Isoelectric focusing was performed for $6 \mathrm{~h}$ reaching a total of $20 \mathrm{kVh}$. After IEF, the strips were transferred to equilibration buffer (6 M urea, $50 \mathrm{mM}$ Tris- $\mathrm{HCl}$ ( $\mathrm{pH} 8.8$ ), 30\% glycerol and 4\% SDS) supplemented with either $1 \%(\mathrm{w} / \mathrm{v})$ DTT or $2.5 \%(\mathrm{w} / \mathrm{v})$ iodoacetamide for $15 \mathrm{~min}$ at room temperature. The IPG strips were then placed onto $12 \%$ polyacrylamide gels and overlaid with $0.5 \%$ agarose in SDS-PAGE running buffer. Gel electrophoresis was carried out at $20^{\circ} \mathrm{C}$ in the Ettan Dalt six systems (GE Healthcare) at $30 \mathrm{~mA}$ per gel for $5 \mathrm{~h}$ and gels were imaged on a Typhoon 9400 Variable Mode Imager (GE Healthcare). Excitation/emission wavelengths for Cy2 (488/520), Cy3 $(532 / 580)$ and Cy5 $(633 / 670 \mathrm{~nm})$ were analyzed with DeCyder 7.0 software (GE Healthcare). The fold change threshold was set at 2.5 -fold to be considered significant. Moreover, spots with a p-value $<0.05$ following a Student's t-test comparing treated plants log standardized abundance values to control values were also considered significance.

\section{In-gel digestion and mass spectrometry}

Protein spots were excised from preparative 2D-gels that had been stained with Coomassie brilliant blue. Spots were destained in $50 \mathrm{mM}$ ammonium bicarbonate $/ 50 \%$ methanol $(\mathrm{v} / \mathrm{v})$ in water, followed by $75 \%$ acetonitrile $(\mathrm{v} / \mathrm{v})$ for dehydration. Spots were then rehydrated with trypsin digestion solution overnight $(20 \mathrm{~h})$ at $37^{\circ} \mathrm{C}$. Digested peptides were extracted using extraction buffer $(50 \%$ Acetonitrile, 0.5\% Trifluoroacetic Acid (TFA)) and dried by vacuum centrifugation. Peptides were dissolved in $0.1 \%$ TFA, desalted with a C18 ZipTip (Millipore, Bedford, MA), mixed with $6 \mathrm{mg} / \mathrm{ml}$ a-cyano-4-hydroxy-cinnamic acid in 50\% acetonitrile and 0.1\% TFA and spotted onto MALDI target plates. Mass spectrometry was performed on a Bruker-Daltonics AutoFlex TOF/TOF LIFT Mass Spectrometer (Bruker Daltonics, Bremen, Germany) operated in reflectron mode. Database searches with both peptide mass fingerprinting (PMF) and MS/MS were performed using the MASCOT program. The database was set to the National Center for Biotechnology nonredundant (NCBInr) (updated on September 4, 2012), which contained 19,737,474 sequences. The other parameters for searching were enzyme of trypsin, one missed cleavage, fixed modifications of carbamidomethyl (Cys), peptide mass tolerance of $100 \mathrm{ppm}$, fragment mass tolerance of \pm 
$0.5 \mathrm{Da}$, peptide charge state of $1+$ and monoisotopic. Only significant hits, as defined by the MASCOT probability analysis $(\mathrm{p}<0.05)$ were accepted.

\section{Dark treatment of leaves in Arabidopsis thaliana and rice and heat shock treatment of rice protoplasts and TMV infected tobacco leaves}

Green leaves from Arabidopsis thaliana and rice were placed onto dishes containing distilled water under continuous dark at $23^{\circ} \mathrm{C}$ [89]. Heat shock was induced in rice protoplasts using a water bath at $48^{\circ} \mathrm{C}$ for $15 \mathrm{~min}$, with samples returned to $28^{\circ} \mathrm{C}$ for recovery [62]. TMV infected tobacco leaves were rubbed with viral suspensions $(1 \mu \mathrm{g} / \mathrm{ml})$ mixed with $20 \mathrm{mg} / \mathrm{ml}$ carborundum carmine in water on to the leaf lamina. After abrasion, carborundum carmine was washed by spraying with water and the tobacco was allowed to grow in greenhouse [90].

\section{Polyamines concentration determination}

Leaf samples $(1 \mathrm{~g})$ were fully ground in liquid nitrogen, soaked in $3 \mathrm{ml}$ of $0.6 \mathrm{M} \mathrm{HClO}_{4}$ for $1 \mathrm{~h}$ on ice, centrifuged for $20 \mathrm{~min}\left(17,000 \times \mathrm{g}, 4^{\circ} \mathrm{C}\right)$ and the $1 \mathrm{ml}$ supernatant mixed with $14 \mu \mathrm{l}$ of benzoyl chloride. $2 \mathrm{ml}$ of $\mathrm{NaOH}$ (2 M) was added to each samples followed by vortexing for $20 \mathrm{~s}$, a $20 \mathrm{~min}$ incubation at $37^{\circ} \mathrm{C}$ and the addition of $2 \mathrm{ml}$ of saturated $\mathrm{NaCl}$. Benzoyl-polyamines were extracted in $2 \mathrm{ml}$ of diethyl ether. After centrifugation at $3000 \times \mathrm{g}$ for $15 \mathrm{~min}, 1 \mathrm{ml}$ of the ether phase was collected,

Table 2 Specific primers used for RT-PCR analysis

\begin{tabular}{|c|c|c|}
\hline Gene & Forward primer & Reverse primer \\
\hline ZmCyclophilin (Zea may) & 5'-atcgtgatggagctgtacgccaa-3' & 5'-tggcacatgaacacggggat-3' \\
\hline ZmTCTP (Zea may) & 5'-cactaatccgacattcctcta-3' & 5'-aacaagcaatccaatcttgg-3' \\
\hline zm50s RPL (Zea may) & 5'-ggttgtgagatgttgtat-3' & 5'-aagaaggatgtatatgttgt-3' \\
\hline ZmPH (Zea may) & 5'-gctacttacgcagagaat-3' & 5'-caccagagttccacataa-3' \\
\hline zmDREPP4 (Zea may) & 5'-gaaggaagaggaggataagc-3' & $5^{\prime}$-ttaccagcagcaagcaag-3' \\
\hline zmFpPKIWI502 (Zea may) & 5'-actactgaacattacatc-3 & 5'- taatcatctcatctcctt-3 \\
\hline zmHSP70 (Zea may) & 5'-aggaggtggactaagcggat-3 & 5'-cttaaaacgcgtgccacgat-3 \\
\hline ZmADK (Zea may) & 5'-agaaggtcctcccgtatgct-3 & $5^{\prime}$-tgcctgaagccaaaggaagt-3 \\
\hline ZmMDH (Zea may) & 5'-cagcggaatgcatttgcca-3 & 5'-tgcatcatagtcaaattcgtgtgg-3 \\
\hline zmOEE1 (Zea may) & $5^{\prime}$-gaccgecgtcatggatctt-3 & 5'-aaaagcgacagcccgaat-3 \\
\hline ZmPGK (Zea may) & $5^{\prime}$-gcgctagcctggaattgttg-3 & 5'-tcggtagcagacctccgtaa-3 \\
\hline ZmPEPCK (Zea may) & 5'-aaacgatggtgtgtgtgcgt-3 & 5'-acaagaccagagaccagacg-3 \\
\hline ZmFbp (Zea may) & $5^{\prime}$-ctccaacgaggtgttctcca-3 & 5'-gaacacgacgatgtagttgcc-3 \\
\hline zm3-Bhsd (Zea may) & 5'-gacgctgtcggagaaccatt-3 & 5'-cagggggtgcaaggattagg-3 \\
\hline zmHrBP1 (Zea may) & 5'-gctcagggtgtttgtcat-3 & 5'-aggaagaaggatggcaatc-3 \\
\hline zmChitinase (Zea may) & 5'-gtcaccaacatcatcaac-3 & $5^{\prime}$-caagcaagtcacagtatc-3 \\
\hline 18S rRNA (Oryza) & 5'- cctatcaactttcgatggtaggata-3' & 5'-cgttaagggatttagattgtactcatt-3' \\
\hline TCTP (Oryza) & $5^{\prime}$-ttcctttacttctctcat-3' & 5'-tcatctcaacatccataa-3' \\
\hline eEF1a (Nicotiana) & $5^{\prime}$-taatgtggttcttagttc-3' & $5^{\prime}$-agttccgaattaagtatc-3' \\
\hline hsr203j (Nicotiana) & $5^{\prime}$-cagagttcatcaacaagcatta -3' & 5'-acaatcaagacggtacatca-3' \\
\hline TCTP (Nicotiana) & 5'-tcaaggagcaaccaagta-3' & 5'-caccattccagtatcatcag-3' \\
\hline Actin (Arabidopsis thaliana) & $5^{\prime}$-gccatccaagctgttctctc-3' & 5'-gctcgtagtcaacagcaacaa-3' \\
\hline TCTP (Arabidopsis thaliana) & $5^{\prime}$-ctgtgttggaagattctca -3' & 5'-agattcgggagtttaatttaga $-3^{\prime}$ \\
\hline HRT (Zea may) & 5'-aagaacctcagaggcaaagc-3' & $5^{\prime}$-acattctcccagaaggctgc-3' \\
\hline CLA (Zea may) & 5'-gctgactccgactttgacga-3' & $5^{\prime}-\operatorname{ctg} c t t t c c t g t c g t c c c t t-3^{\prime}$ \\
\hline SAMS2 (Zea may) & $5^{\prime}$-ccctttcggtgttcgtgga-3' & 5'-acagcacagcactgcaacat-3' \\
\hline zm-PImbp (Zea may) & $5^{\prime}$-ctttgctgggctgatttccg-3' & 5'-tcttgccttcgtctcgcaat-3' \\
\hline IAA/AUIX (Zea may) & $5^{\prime}$-ttacagtccagagcaaga-3' & 5'-tacagaccataagg cagaa-3' \\
\hline ACS6 (Zea may) & 5'-agctgtggaagaaggtggtcttcgaggt-3' & 5'-agtacgtgaccgtggtttctatga--3' \\
\hline ACO15 (Zea may) & $5^{\prime}$-ctcgtcttcgatcaattcccaagt-3' & 5'-tacattatcattatttctccggctgt-3' \\
\hline SAMDC2 (Zea may) & 5'-gaaaggcacttggtgcagag-3' & 5'-ccgtcaaagcagtggaaaaca-3' \\
\hline
\end{tabular}


evaporated to dryness in a vacuum concentrator and redissolved in $100 \mu \mathrm{l}$ of methanol. Polyamine standards were processed in a similar way to benzoylate, with $10 \mu \mathrm{l}$ aliquots of each redissolved sample were injected into a Liquid Chromatograph. The samples were eluted through a $150 \times 3.9 \mathrm{~mm}, 4 \mu \mathrm{m}$ particle size $\mathrm{C} 18$ reverse-phase column at a flow rate of $0.7 \mathrm{ml} / \mathrm{min}$. The detection wavelength was $230 \mathrm{~nm}$ and the column was held at $30^{\circ} \mathrm{C}$ [91].

\section{Ethylene concentration determination}

The third leaves of the control and flooding treatments of maize were confined in $25 \mathrm{ml}$ sealed glass flasks without agitation. In order to prevent any stress, incubation conditions were the same as culture conditions. After a $24 \mathrm{~h}$ dark incubation, at $28^{\circ} \mathrm{C}, 1 \mathrm{ml}$ of gas was taken from the flask with a gas-tight syringe and analyzed using gas chromatograph (GC). An $\mathrm{Al}_{2} \mathrm{O}_{3}(30 \mathrm{~m} \times 0.53 \mathrm{~mm} \times 1.5 \mu \mathrm{m})$ capillary column was used with a carrier gas $\left(\mathrm{N}_{2}\right)$ and flow rate of $48 \mathrm{ml} / \mathrm{min}$. The spray, column and detector temperatures were maintained at $130^{\circ} \mathrm{C}, 40^{\circ} \mathrm{C}$ and $220^{\circ} \mathrm{C}$ respectively [92].

\section{GA, IAA, ABA concentration determination}

Tissue samples (0.5 g fresh weight) were ground to a powder under liquid nitrogen and soaked in $5 \mathrm{ml}$ of $80 \%$ methanol at $4^{\circ} \mathrm{C}$ for $12 \mathrm{~h}$, centrifuged for $15 \mathrm{~min}$ $(14000 \mathrm{rpm})$ and the supernatant collected, with the centrifugation and supernatant collection repeat twice. The samples were concentrated to $5 \mathrm{ml}$ under nitrogen gas, passed through Sep Pak $\mathrm{C}^{18}$-cartridges and the hormones eluted with $80 \%$ methanol. The eluates were then dried under nitrogen gas, extracted in $1 \mathrm{ml}$ of $60 \%$ methanol in $1 \%$ acetic acid in distilled water and passed through a $0.45 \mu \mathrm{m}$ filter prior to loading. The hormones were then analyzed by ultra-performance liquid chromatography (UPLC) using mobile phase A (1\% acetic acid in distilled water) and $B$ (methanol) to give $A: B=6: 4$. The column was held at $35^{\circ} \mathrm{C}$ with a flow rate of $1.0 \mathrm{ml} / \mathrm{min}$ and a detection wavelength of $260 \mathrm{~nm}$ [93].

\section{Quantitative real-time RT-PCR (qRT-PCR) analysis}

Total RNA was prepared from various samples with TRIZOL reagent (Invitrogen) according to the manufacturer's instructions. Cyclophilin, $18 \mathrm{~S}$ rRNA, actin and eEF1 $\alpha$ were used as internal controls for the normalization of maize, rice, Arabidopsis thaliana and tobacco respectively [94-97]. Primers were designed for qRT-PCR analysis (Table 2) and all of the RNA samples were diluted to $200 \mathrm{ng} / \mu \mathrm{l}$. Expression levels were evaluated using a twostep qRT-PCR kit with $\mathrm{SYBR}^{\circ}$ Green (Takara) with a final volume of $20 \mu \mathrm{l}\left(10 \mu \mathrm{l} \mathrm{SYBR}{ }^{\circ}\right.$ Green qPCR Mixture, $10 \mu \mathrm{M}$ forward and reverse primers) in a 7500 Real time PCR System (ABI). All reactions were performed in three biological replicates. The threshold cycle values (Ct value) of the genes and internal control genes for the different samples were calculated by the $2^{-\Delta \Delta C T}$ method, and the mean \pm SD should always be calculated after the $2^{-\Delta \Delta C T}$ transformation in order to perform statistical analysis [98].

\section{Statistical analysis}

Statistical procedures were carried out with the software package SPSS 10.0 for Windows. The means were considered to be significantly different by Fisher's protected LSD test at $\mathrm{p}<0.05$.

\section{Abbreviations}

2D-DIGE: Two-dimensional fluorescence difference gel electrophoresis; ABA: Abscisic acid; ACS: 1-aminocyclopropane-1-carboxylate synthase; ACO: 1-aminocyclopropane-1-carboxylate oxidase; AMP: Adenosine monophosphates; CHAPS: 3-[(3-cholamidopropyl)dimethylammonio]-1propanesulfonate; DAB: 3,3-diaminobenzidine; DMF: Dimethylformamide; DREPP 4: Developmentally regulated response 4; DTT: Dithiothreitol; ET: Ethylene; GA: Gibberellin acid; GARE: Gibberellin response element; GC: Gas chromatograph; HR: Hypersensitivity; HrBP1: Harpin binding protein 1; IAA: Indole acetic acid; LSD: Least significant difference; MALDI: Matrix-asscisted laser desorption/ionization; OEE1: Oxygen-evolving enhancer protein 1; PCD: Programmed cell death; PMF: Fingerprinting; PMSF: Phenylmethylsulfonyl fluoride; PPV: Plum pox virus; PSII: Photosystem II; PVPP: Polyvinylpolypyrrolidone; PUT: Putrescine; qRT-PCR: Quantitive real-time PCR; ROS: Reactive oxygen species; RWC: Relative water content; SAM: S-adenosyl-L-methionine; SAMDC:

S-adenosylmethionine decarboxylase; SAMS2: S-adenosylmethionine synthase 2; SPD: Spermidine; SPM: Spermine; TCA: Trichloroacetic acid; TCTP: Translationallycontrolled tumor protein; TFA: Trifluoroacetic acid; TOF: Time-of-flight;

UPLC: Ultra-performance liquid chromatography.

\section{Competing interests}

The authors declare that they have no competing interests.

\section{Authors' contributions}

CY carried out all experiments in addition to the detection of DNA ladder. WHJ carried out the detection of DNA ladder. CX, BYQ, ZW conceived designed and coordinated this study. All authors read and approved the final manuscript.

\section{Acknowledgements}

This work was supported by the National Natural Science Foundation of China (31171326, 31301839), the Natural Science Foundation of Jiangsu Province of China (BK20130672), and a project funded by the Fundamental Research Funds for the Central Universities-Nanjing Agricultural University Youth Science and Technology Innovation Fund (KJ2013030). The identification of proteins by MALDI-TOF/TOF Mass Spectrometer was performed in Research Centre for Proteome Analysis (RCPA), Shanghai Institutes for Biological Sciences, Shanghai, China.

Received: 17 February 2014 Accepted: 30 May 2014

Published: 11 June 2014

\section{Reference}

1. Reape TJ, Molony EM, McCabe PF: Programmed cell death in plants: distinguishing between different modes. J Exp Bot 2008, 59:435-444.

2. Greenberg JT: Programmed cell death: a way of life for plants. Proc Natl Acad Sci U S A 1996, 93:12094-12097.

3. Kuriyama H, Fukuda H: Developmental programmed cell death in plants. Curr Opin Plant Biol 2002, 5:568-573.

4. Lam E, Kato N, Lawton M: Programmed cell death, mitochondria and the plant hypersensitive response. Nature 2001, 411:848-853.

5. Balk J, Leaver CJ, McCabe PF: Translocation of cytochrome c from the mitochondria to the cytosol occurs during heat-induced programmed cell death in cucumber plants. FEBS Lett 1999, 463:151-154.

6. Huh GH, Damsz B, Matsumoto TK, Reddy MP, Rus AM, Ibeas Jl, Narasimhan ML, Bressan RA, Hasegawa PM: Salt causes ion disequilibrium-induced programmed cell death in yeast and plants. Plant J 2002, 29:649-659. 
7. Jackson MB, Colmer TD: Response and adaptation by plants to flooding stress. Ann Bot 2005, 96:501-505.

8. Aggarwal PK, Banerjee B, Daryaei MG, Bhatia A, Bala A, Rani S, Chander S, Pathak H, Kalra N: InfoCrop: a dynamic simulation model for the assessment of crop yields, losses due to pests, and environmental impact of agro-ecosystems in tropical environments. II. Performance of the model. Agr Syst 2006, 89:47-67.

9. Qiu FZ, Zheng YL, Zhang ZL, Xu SZ: Mapping of QTL associated with waterlogging tolerance during the seedling stage in maize. Ann Bot 2007, 99:1067-1081.

10. Lenochova Z, Soukup A, Votrubova O: Aerenchyma formation in maize roots. Biol Plantarum 2009, 53:263-270.

11. Ahsan N, Lee DG, Lee SH, Kang KY, Bahk JD, Choi MS, Lee IJ, Renaut J, Lee $\mathrm{BH}$ : A comparative proteomic analysis of tomato leaves in response to waterlogging stress. Physiol Plant 2007, 131:555-570.

12. Sadiq I, Fanucchi F, Paparelli E, Alpi E, Bachi A, Alpi A, Perata P: Proteomic identification of differentially expressed proteins in the anoxic rice coleoptile. J Plant Physiol 2011, 168:2234-2243.

13. Komatsu S, Yamamoto R, Nanjo Y, Mikami Y, Yunokawa H, Sakata K: A comprehensive analysis of the soybean genes and proteins expressed under flooding stress using transcriptome and proteome techniques. J Proteome Res 2009, 8:4766-4778.

14. Kong FJ, Oyanagi A, Komatsu S: Cell wall proteome of wheat roots under flooding stress using gel-based and LC MS/MS-based proteomics approaches. Bba-Proteins Proteom 1804, 2010:124-136.

15. Chang WWP, Huang L, Shen M, Webster C, Burlingame AL, Roberts JKM: Patterns of protein synthesis and tolerance of anoxia in root tips of maize seedlings acclimated to a low-oxygen environment, and identification of proteins by mass spectrometry. Plant Physiol 2000, 122:295-317.

16. Subbaiah CC, Sachs MM: Molecular and cellular adaptations of maize to flooding stress. Ann Bot 2003, 91:119-127.

17. Netondo GW, Onyango JC, Beck E: Sorghum and salinity: II. Gas exchange and chlorophyll fluorescence of sorghum under salt stress. Crop Sci 2004, 44:806-811.

18. Öquist G, Anderson JM, McCaffery S, Chow W: Mechanistic differences in photoinhibition of sun and shade plants. Planta 1992, 188:422-431.

19. Björkman O, Powles SB: Inhibition of photosynthetic reactions under water stress: interaction with light level. Planta 1984, 161:490-504.

20. Horton P, Ruban A, Walters R: Regulation of light harvesting in green plants. Annu Rev Plant Biol 1996, 47:655-684.

21. Moradi F, Ismail AM: Responses of photosynthesis, chlorophyll fluorescence and ROS-Scavenging systems to salt stress during seedling and reproductive stages in rice. Ann Bot 2007, 99:1161-1173.

22. Rahoutei J, García-Luque I, Barón M: Inhibition of photosynthesis by viral infection: effect on PSII structure and function. Physiol Plant 2000, 110:286-292.

23. Diaz-Vivancos P, Clemente-Moreno MJ, Rubio M, Olmos E, Garcia JA, Martinez-Gomez P, Hernandez JA: Alteration in the chloroplastic metabolism leads to ROS accumulation in pea plants in response to plum pox virus. J Exp Bot 2008, 59:2147-2160

24. Parlanti S, Kudahettige NP, Lombardi L, Mensuali-Sodi A, Alpi A, Perata P, Pucciariello C: Distinct mechanisms for aerenchyma formation in leaf sheaths of rice genotypes displaying a quiescence or escape strategy for flooding tolerance. Ann Bot 2011, 107:1335-1343.

25. Fan HY, Zhou ZQ, Yang CN, Jiang Z, Li JT, Cheng XX, Guo YJ: Effects of waterlogging on amyloplasts and programmed cell death in endosperm cells of Triticum aestivum L. Protoplasma 2013, 250:1091-1103.

26. Lovegrove A, Hooley R: Gibberellin and abscisic acid signalling in aleurone. Trends Plant Sci 2000, 5:102-110

27. Thirunavukkarasu N, Hossain F, Mohan S, Shiriga K, Mittal S, Sharma R, Singh RK, Gupta HS: Genome-wide expression of transcriptomes and their co-expression pattern in subtropical maize (Zea mays L.) under waterlogging stress. PLOS One 2013, 8:e70433.

28. Chen G, Gharib TG, Huang CC, Taylor JM, Misek DE, Kardia SL, Giordano TJ, lannettoni MD, Orringer MB, Hanash SM, Beer DG: Discordant protein and mRNA expression in lung adenocarcinomas. Mol Cell Proteomics 2002, 1:304-313.

29. Yan SP, Zhang QY, Tang ZC, Su WA, Sun WN: Comparative proteomic analysis provides new insights into chilling stress responses in rice. Mol Cell Proteomics 2006, 5:484-496.

30. Zhao PM, Wang LL, Han LB, Wang J, Yao Y, Wang HY, Du XM, Luo YM, Xia GX: Proteomic identification of differentially expressed proteins in the ligon lintless mutant of upland cotton (Gossypium hirsutum L.). J Proteome Res 2010, 9:1076-1087.

31. Stoychev V, Simova-Stoilova L, Vaseva I, Kostadinova A, Nenkova R, Feller U, Demirevska K: Protein changes and proteolytic degradation in red and white clover plants subjected to waterlogging. Acta Physiologiae Plantarum 2013, 35:1925-1932.

32. Ono Y, Wada S, Izumi M, Makino A, Ishida H: Evidence for contribution of autophagy to Rubisco degradation during leaf senescence in Arabidopsis thaliana. Plant Cell Environ 2013, 36:1147-1159.

33. Khanna-Chopra R: Leaf senescence and abiotic stresses share reactive oxygen species-mediated chloroplast degradation. Protoplasma 2012, 249:469-481.

34. Minamikawa T, Toyooka K, Okamoto T, Hara-Nishimura I, Nishimura M: Degradation of ribulose-bisphosphate carboxylase by vacuolar enzymes of senescing French bean leaves: immunocytochemical and ultrastructural observations. Protoplasma 2001, 218:144-153.

35. Parker R, Flowers TJ, Moore AL, Harpham NV: An accurate and reproducible method for proteome profiling of the effects of salt stress in the rice leaf lamina. J Exp Bot 2006, 57:1109-1118.

36. Sugihara K, Hanagata N, Dubinsky Z, Baba S, Karube I: Molecular characterization of cDNA encoding oxygen evolving enhancer protein 1 increased by salt treatment in the mangrove Bruguiera gymnorrhiza. Plant Cell Physiol 2000, 41:1279-1285.

37. Fatehi F, Hosseinzadeh A, Alizadeh H, Brimavandi T: The proteome response of hordeum spontaneum to salinity stress. Cereal Res Commun 2013, 41:78-87.

38. Ngamhui NO, Akkasaeng C, Zhu YJ, Tantisuwichwong N, Roytrakul S, Sansayawichai T: Differentially expressed proteins in sugarcane leaves in response to water deficit stress. Plant Omics 2012, 5:365-371.

39. Lagrange T, Franzetti $B$, Axelos M, Mache R, Lerbs-Mache S: Structure and expression of the nuclear gene coding for the chloroplast ribosomal protein L21: developmental regulation of a housekeeping gene by alternative promoters. Mol Cell Biol 1993, 13:2614-2622.

40. Kreuzwieser J, Papadopoulou E, Rennenberg $\mathrm{H}$ : Interaction of flooding with carbon metabolism of forest trees. Plant Biol (Stuttg) 2004, 6:299-306.

41. Moffatt BA, Wang L, Allen MS, Stevens YY, Qin W, Snider J, von Schwartzenberg K: Adenosine kinase of Arabidopsis. Kinetic properties and gene expression. Plant Physiol 2000, 124:1775-1785.

42. Lee KW, Chen PW, Lu CA, Chen S, Ho THD, Yu SM: Coordinated responses to oxygen and sugar deficiency allow rice seedlings to tolerate flooding. Sci Signal 2009, 2:ra61.

43. Majoul T, Bancel E, Triboi E, Ben Hamida J, Branlard G: Proteomic analysis of the effect of heat stress on hexaploid wheat grain: characterization of heat-responsive proteins from non-prolamins fraction. Proteomics 2004, 4:505-513.

44. Lin KHR, Weng CC, Lo HF, Chen JT: Study of the root antioxidative system of tomatoes and eggplants under waterlogged conditions. Plant Sci 2004, 167:355-365.

45. Lee J, Bricker TM, Lefevre M, Pinson SR, Oard JH: Proteomic and genetic approaches to identifying defence-related proteins in rice challenged with the fungal pathogen Rhizoctonia solani. Mol Plant Pathol 2006, 7:405-416.

46. Wei ZM, Laby RJ, Zumoff CH, Bauer DW, He SY, Collmer A, Beer SV: Harpin elicitor of the hypersensitive response produced by the plant pathogen erwinia-amylovora. Science 1992, 257:85-88.

47. Liu F, Liu H, Jia Q, Wu X, Guo X, Zhang S, Song F, Dong H: The internal glycine-rich motif and cysteine suppress several effects of the HpaG (Xooc) protein in plants. Phytopathology 2006, 96:1052-1059.

48. Punja ZK, Zhang YY: Plant chitinases and their roles in resistance to fungal diseases. J Nematol 1993, 25:526-540.

49. Dani V, Simon WJ, Duranti M, Croy RRD: Changes in the tobacco leaf apoplast proteome in response to salt stress. Proteomics 2005, 5:737-745.

50. Diaz-Vivancos P, Rubio M, Mesonero V, Periago PM, Barcelo AR, Martinez-Gomez P, Hernandez JA: The apoplastic antioxidant system in Prunus: response to long-term plum pox virus infection. J Exp Bot 2006, 57:3813-3824.

51. Barba-Espin G, Clemente-Moreno MJ, Alvarez S, Garcia-Legaz MF, Hernandez JA, Diaz-Vivancos P: Salicylic acid negatively affects the response to salt stress in pea plants. Plant Biol (Stuttg) 2011, 13:909-917.

52. Komatsu S, Yamamoto A, Nakamura T, Nouri MZ, Nanjo Y, Nishizawa K, Furukawa K: Comprehensive analysis of mitochondria in roots and 
hypocotyls of soybean under flooding stress using proteomics and metabolomics techniques. J Proteome Res 2011, 10:3993-4004.

53. Baritaud M, Boujrad H, Lorenzo HK, Krantic S, Susin SA: Histone H2AX The missing link in AIF-mediated caspase-independent programmed necrosis. Cell Cycle 2010, 9:3166-3173.

54. Gomes I, Xiong W, Miki T, Rosner MR: A proline- and glutamine-rich protein promotes apoptosis in neuronal cells. J Neurochem 1999, 73:612-622.

55. Park CG, Lee SY, Kandala G, Lee SY, Choi Y: A novel gene product that couples TCR signaling to Fas(CD95) expression in activation-induced cell death. Immunity 1996, 4:583-591.

56. Neef R, Kuske MA, Prols E, Johnson JP: Identification of the human PHLDA1/TDAG51 gene: down-regulation in metastatic melanoma contributes to apoptosis resistance and growth deregulation. Cancer Res 2002, 62:5920-5929.

57. Logan DC, Domergue O, de la Serve BT, Rossignol M: A new family of plasma membrane polypeptides differentially regulated during plant development. Biochem Mol Biol Int 1997, 43:1051-1062.

58. Cheng YW, Qi YC, Zhu Q, Chen X, Wang N, Zhao X, Chen HY, Cui XJ, Xu L, Zhang $W$ : New changes in the plasma-membrane-associated proteome of rice roots under salt stress. Proteomics 2009, 9:3100-3114.

59. Kawamura Y, Uemura M: Mass spectrometric approach for identifying putative plasma membrane proteins of Arabidopsis leaves associated with cold acclimation. Plant J 2003, 36:141-154.

60. Mohammadi M, Anoop V, Gleddie S, Harris LJ: Proteomic profiling of two maize inbreds during early gibberella ear rot infection. Proteomics 2011, 11:3675-3684

61. Komatsu S, Makino T, Yasue H: Proteomic and biochemical analyses of the cotyledon and root of flooding-stressed soybean plants. PLoS One 2013, 8:e65301.

62. Qi YC, Wang HJ, Zou Y, Liu C, Liu YQ, Wang Y, Zhang W: Over-expression of mitochondrial heat shock protein 70 suppresses programmed cell death in rice. FEBS Lett 2011, 585:231-239.

63. Gnanasekar M, Dakshinamoorthy G, Ramaswamy K: Translationally controlled tumor protein is a novel heat shock protein with chaperone-like activity. Biochem Biophys Res Commun 2009, 386:333-337.

64. You LP, Ning XX, Liu F, Zhao JM, Wang Q, Wu HF: The response profiles of HSPA12A and TCTP from Mytilus galloprovincialis to pathogen and cadmium challenge. Fish Shellfish Immun 2013, 35:343-350.

65. Hoepflinger MC, Reitsamer J, Geretschlaeger AM, Mehlmer N, Tenhaken R: The effect of Translationally Controlled Tumour Protein (TCTP) on programmed cell death in plants. BMC Plant Bio/ 2013, 13:135.

66. Barba-Espin G, Diaz-Vivancos P, Clemente-Moreno M, Albacete A, Faize L, Faize M, Pérez-Alfocea F, Hernández J: Interaction between hydrogen peroxide and plant hormones during germination and the early growth of pea seedlings. Plant Cell Environ 2010, 33:981-994.

67. Peeters AJ, Cox MC, Benschop JJ, Vreeburg RA, Bou J, Voesenek LA: Submergence research using Rumex palustris as a model; looking back and going forward. J Exp Bot 2002, 53:391-398.

68. Shu S, Guo S-R, Yuan L-Y: A review: polyamines and photosynthesis. In Advances in Photosynthesis-Fundamental Aspects InTech. Croatia: Open Access Publisher; 2012:439-464

69. Chen R, Binder BM, Garrett WM, Tucker ML, Chang C, Cooper B: Proteomic responses in Arabidopsis thaliana seedlings treated with ethylene. Mol Biosyst 2011, 7:2637-2650.

70. Kim SG, Wang Y, Lee CN, Mun BG, Kim PJ, Lee SY, Kim YC, Kang KY, Rakwal R, Agrawal GK, Kim ST: A comparative proteomics survey of proteins responsive to phosphorous starvation in roots of hydroponically-grown rice seedlings. J Korean Soc Appl Bi 2011, 54:667-677.

71. Wang KL, Li H, Ecker JR: Ethylene biosynthesis and signaling networks. Plant Cell 2002, 14(Suppl):S131-S151.

72. Li ZY, Chen SY: Differential accumulation of the S-adenosylmethionine decarboxylase transcript in rice seedlings in response to salt and drought stresses. Theor Appl Genet 2000, 100:782-788.

73. Malladi A, Burns JK: Communication by plant growth regulators in roots and shoots of horticultural crops. Hort Science 2007, 42:1113-1117.

74. Hsu FC, Chou MY, Peng HP, Chou SJ, Shih MC: Insights into hypoxic systemic responses based on analyses of transcriptional regulation in Arabidopsis. PLoS One 2011, 6:e28888.

75. Beauchamp C, Fridovich I: A mechanism for the production of ethylene from methional. The generation of the hydroxyl radical by xanthine oxidase. J Biol Chem 1970, 245:4641-4646.
76. Komatsu S, Hiraga S, Yanagawa Y: Proteomics techniques for the development of flood tolerant crops. J Proteome Res 2012, 11:68-78.

77. Tsai W-C, Hsiao Y-Y, Pan Z-J, Kuoh C-S, Chen W-H, Chen H-H: The role of ethylene in orchid ovule development. Plant Sci 2008, 175:98-105.

78. Rogers SW, Rogers JC: Cloning and characterization of a gibberellin-induced RNase expressed in barley aleurone cells. Plant Physiol 1999, 119:1457-1464.

79. Zhang J, Davies WJ: Aba in roots and leaves of flooded pea-plants. J Exp Bot 1987, 38:649-659.

80. Olivella C, Biel C, Vendrell M, Save R: Hormonal and physiological responses of Gerbera jamesonii to flooding stress. Hort Science 2000, 35:222-225.

81. Tiwari SB, Wang XJ, Hagen G, Guilfoyle TJ: AUX/IAA proteins are active repressors, and their stability and activity are modulated by auxin. Plant Cell 2001, 13:2809-2822.

82. Yan B, Dai QJ, Liu XZ, Huang SB, Wang ZX: Flooding-induced membrane damage, lipid oxidation and activated oxygen generation in corn leaves. Plant Soil 1996, 179:261-268.

83. Vankooten O, Snel JFH: The use of chlorophyll fluorescence nomenclature in plant stress physiology. Photosynth Res 1990, 25:147-150.

84. Turner NC: Techniques and experimental approaches for the measurement of plant water status. Plant Soil 1981, 58:339-366.

85. Zhang AY, Jiang MY, Zhang JH, Tan MP, Hu XL: Mitogen-activated protein kinase is involved in abscisic acid-induced antioxidant defense and acts downstream of reactive oxygen species production in leaves of maize plants. Plant Physiol 2006, 141:475-487.

86. Chen X, Wang Y, Li J, Jiang A, Cheng Y, Zhang W: Mitochondrial proteome during salt stress-induced programmed cell death in rice. Plant Physiol Biochem 2009, 47:407-415.

87. Kim ST, Cho KS, Jang YS, Kang KY: Two-dimensional electrophoretic analysis of rice proteins by polyethylene glycol fractionation for protein arrays. Electrophoresis 2001, 22:2103-2109.

88. Tannu NS, Hemby SE: Two-dimensional fluorescence difference gel electrophoresis for comparative proteomics profiling. Nat Protoc 2006, 1:1732-1742.

89. Roberts IN, Passeron S, Barneix AJ: The two main endoproteases present in dark-induced senescent wheat leaves are distinct subtilisin-like proteases. Planta 2006, 224:1437-1447.

90. Bi YM, Kenton P, Mur L, Darby R, Draper J: Hydrogen peroxide does not function downstream of salicylic acid in the induction of PR protein expression. Plant J 1995, 8:235-245.

91. Chen $C T$, Kao CH: Senescence of rice leaves XXX levels of endogenous polyamines and dark-induced senescence of rice leaves. Plant Cell Physiol 1991, 32:935-941.

92. Fišerová H, Mikušová Z, Klemš M: Estimation of ethylene production and 1-aminocyclopropane-1-carboxylic acid content in plants by means of gas chromatography. Plant Soil Environ 2008, 54:55-60.

93. Symons GM, Chua YJ, Ross JJ, Quittenden LJ, Davies NW, Reid JB: Hormonal changes during non-climacteric ripening in strawberry. J Exp Bot 2012, 63:4741-4750

94. Campo S, Peris-Peris C, Montesinos L, Penas G, Messeguer J, Segundo BS Expression of the maize ZmGF14-6 gene in rice confers tolerance to drought stress while enhancing susceptibility to pathogen infection. J Exp Bot 2012, 63:983-999.

95. Jain M, Nijhawan A, Tyagi AK, Khurana JP: Validation of housekeeping genes as internal control for studying gene expression in rice by quantitative real-time PCR. Biochem Biophys Res Commun 2006, 345:646-651.

96. Jia XY, Wang WX, Ren LG, Chen QJ, Mendu V, Willcut B, Dinkins R, Tang XQ, Tang GL: Differential and dynamic regulation of miR398 in response to $A B A$ and salt stress in Populus tremula and Arabidopsis thaliana. Plant Mol Biol 2009, 71:51-59.

97. Takahashi Y, Uehara Y, Berberich T, Ito A, Saitoh H, Miyazaki A, Terauchi R, Kusano T: A subset of hypersensitive response marker genes, including HSR203J, is the downstream target of a spermine signal transduction pathway in tobacco. Plant J 2004, 40:586-595.

98. Schmittgen TD, Livak KJ: Analyzing real-time PCR data by the comparative C(T) method. Nat Protoc 2008, 3:1101-1108.

doi:10.1186/1477-5956-12-33

Cite this article as: Chen et al: Examination of the leaf proteome during flooding stress and the induction of programmed cell death in maize. Proteome Science 2014 12:33. 